\title{
Synthesis, Crystal Structure, and Biological Evaluation of Novel 5-Hydroxymethylpyrimidines
}

\author{
Marcin Stolarczyk ${ }^{1}$, Agnieszka Matera-Witkiewicz ${ }^{2, *}$, Aleksandra Wolska ${ }^{2}$, Magdalena Krupińska ${ }^{2}$, \\ Aleksandra Mikołajczyk ${ }^{2}$, Anna Pyra ${ }^{3}$ iD and Iwona Bryndal ${ }^{1}$ (D) \\ 1 Department of Organic Chemistry and Drug Technology, Faculty of Pharmacy, Wroclaw Medical University, \\ 211A Borowska, 50-556 Wroclaw, Poland; marcin.stolarczyk@umw.edu.pl (M.S.); \\ iwona.bryndal@umw.edu.pl (I.B.) \\ 2 Screening Biological Activity Assays and Collection of Biological Material Laboratory, Wroclaw Medical \\ University, 211A Borowska, 50-556 Wroclaw, Poland; aleksandra.wolska@umw.edu.pl (A.W.); \\ magdalena.krupinska@umw.edu.pl (M.K.); aleksandra.mikolajczyk@umw.edu.pl (A.M.) \\ 3 Faculty of Chemistry, University of Wroclaw, Joliot-Curie Street 14, 50-383 Wroclaw, Poland; \\ anna.pyra@chem.uni.wroc.pl \\ * Correspondence: agnieszka.matera-witkiewicz@umw.edu.pl; Tel.: +48-71-784-06-68
}

\section{check for} updates

Citation: Stolarczyk, M.; Matera-Witkiewicz, A.; Wolska,

A.; Krupińska, M.; Mikołajczyk,

A.; Pyra, A.; Bryndal, I. Synthesis,

Crystal Structure, and Biological

Evaluation of Novel

5-Hydroxymethylpyrimidines. Materials 2021, 14, 6916. https:// doi.org/10.3390/ma14226916

Academic Editors: Jacek Ścianowski and Marek Krzeminski

Received: 5 September 2021

Accepted: 3 November 2021

Published: 16 November 2021

Publisher's Note: MDPI stays neutral with regard to jurisdictional claims in published maps and institutional affiliations.

Copyright: (c) 2021 by the authors. Licensee MDPI, Basel, Switzerland. This article is an open access article distributed under the terms and conditions of the Creative Commons Attribution (CC BY) license (https:/ / creativecommons.org/licenses/by/ $4.0 /)$.

\begin{abstract}
Pyrimidine displays a wide array of bioactivities, and thence, it is still considered a potent unit of new drug research. Its derivative, 5-hydroxymethylpyrimidine, can be found as a scaffold of nontypical nitrogen bases in DNA and as a core of some natural bioactive compounds. In this study, we obtained a series of 5-hydroxymethylpyrimidines that vary in the 4-position by the reduction of proper esters. All compounds were characterized by spectroscopic analysis, and single-crystal X-ray diffraction was performed for some of them. Biological investigations estimated cytotoxic properties against normal (RPTEC) and cancer (HeLa, HepaRG, Caco-2, AGS, A172) cell lines. It was found that the derivatives with an aliphatic amino group at the 4-position are generally less toxic to normal cells than those with a benzylsulfanyl group. Moreover, compounds with bulky constituents exhibit better anticancer properties, though at a moderate level. The specific compounds were chosen due to their most promising IC50 concentration for in silico study. Furthermore, antimicrobial activity tests were performed against six strains of bacteria and one fungus. They demonstrated that only derivatives with at least three carbon chain amino groups at the 4-position have weak antibacterial properties, and only the derivative with 4-benzylsulfanyl constituent exhibits any antifungal action.
\end{abstract}

Keywords: pyrimidines; anticancer activity; single-crystal X-ray diffraction

\section{Introduction}

The pyrimidine ring is a well-known and established constituent of many synthetic drugs commonly used in medicine that demonstrate a variety of pharmacological activities, especially antimicrobial (e.g., trimethoprim, pyrimethamine, zidovudine, flucytosine) and antineoplastic (e.g., fluorouracil, gemcitabine, cytarabine) [1]. It is still among the leading compounds investigated by medicinal chemists for practical clinical applications of its derivatives [2]. It is also ubiquitous in nature due to the presence of nitrogenous bases in DNA and RNA.

The vast majority of pyrimidines present in nucleic acids are cytosine, thymine, and uracil. Other pyrimidine bases occur rarely and constitute only a small fraction of nucleobases [3]. Modifications in the structures of nucleobases include the process of methylation at the 5-position of the pyrimidine ring and further oxidation of this group by TET (ten-eleven translocation) family proteins [4] to form 5-hydroxymethylcytosine (hmC) (Figure 1a) [5] or 5-hydroxymethyluracil (5-hmU) (Figure 1b) [6]. The function of the mentioned nucleobases is still unclear, but they are thought to regulate gene expression or prompt DNA demethylation [7]. The role of TET proteins in cancer formation was 
also noticed [8], and TET1 was highlighted as a promising target for the treatment of therapy-resistant cancer [9].<smiles>Nc1nc(=O)[nH]cc1CO</smiles>

a<smiles>O=c1[nH]cc(CO)c(=O)[nH]1</smiles>

$\mathrm{b}$<smiles>COc1ncc(CO)c(N)n1</smiles>

C<smiles>Cc1ncc(CO)c(N)n1</smiles>

d

Figure 1. Naturally occurring 5-hydroxymethylpyrimidine derivatives: (a) 5-hydroxymethylcytosine; (b) 5-hydroxymethyluracil; (c) bacimethrin; (d) vitamin $\mathrm{B}_{1}$ (thiamine).

The 5-hydroxymethylpyrimidine scaffold can also be found in a naturally occurring antibiotic, bacimethrin (Figure 1c), isolated from Bacillus megaterium [10]. The structural resemblance between bacimethrin and toxopyrimidine (Figure 1d), which is the pyrimidine part of vitamin $B_{1}$ (thiamine), lies behind its mechanism of action that involves its conversion to 2'-methoxy-thiamin pyrophosphate. It may act as a thiamin-pyrophosphatedependent enzyme or gene inhibitor [11]. The antibiotic and its analogs exhibit antibacterial and anticancer properties [12].

In our previous publications, we reported that 5-hydroxymethylpyrimidine with a tetrasulfide bridge at the 4-position has interesting antibacterial and antifungal properties. Its MIC ranged from 4 to $32 \mathrm{mg} / \mathrm{mL}$, depending on the strain [13]. Additionally, we observed that the hydroxylation of 4-[(4-chlorobenzyl)sulfanyl]-5,6-dimethyl-2phenylpyrimidine to its 5-hydroxymethyl derivative enhances the cytotoxicity significantly towards both normal (survival of normal human endothelial cells, $58 \%$ vs. $1 \%$ ) and cancer cell lines (IC50 in the range $>100-55 \mu \mathrm{M}$ vs. $17-38 \mu \mathrm{M}$, depending on the cancer cell line) [14].

In the continuation of our foregoing research, we present the results of the cytotoxic and antimicrobial study of a series of 5-hydroxymethylpyrimidines that vary in the 4position and a comparison of their structural properties and biological activity.

\section{Materials and Methods}

\subsection{Synthesis}

Reagents were purchased and used without purification. Amines; benzyl chlorides; $\mathrm{LiAlH}_{4}$ (lithium aluminum hydride), reagent grade 95; $\mathrm{POCl}_{3}$; silica gel, 200-400 mesh, $60 \AA$ for column chromatography; and solvents for NMR spectroscopy were supplied by Merck, Darmstadt, Germany. Other reagents were provided by Chempur, Piekary Śląskie, Poland. TLC sheets, Alugram SIL G/UV254, were obtained from Macherey-Nagel, Düren, Germany.

All melting points were uncorrected and determined by the open capillary method with an Electrothermal IA9100 melting point apparatus. NMR spectra were recorded using a Bruker ARX $300 \mathrm{MHz}$ NMR spectrometer. The abbreviations used in NMR spectra are: $\mathrm{s}$-singlet, $\mathrm{d}$-doublet, $\mathrm{t}$ - triplet, $\mathrm{q}$-quartet, and $\mathrm{m}$-multiplet. IR spectra were recorded with a Thermo Scientific USA Nicolet iS50 FTIR using the ATR technique. MS spectra were recorded with a Bruker Daltonic Compact using the ESI technique.

\subsubsection{General Procedure for the Preparation of $\mathbf{2 a}$ and $\mathbf{2} \mathbf{b}$}

Ethyl 4-methyl-2-phenyl-6-sulfanylpyrimidine-5-carboxylate (1a) (2.74 g, $10 \mathrm{mmol})$ [15] was dissolved in a mixture of methanol $(20 \mathrm{~mL})$ and $\mathrm{NaOH}(0.40 \mathrm{~g}, 10 \mathrm{mmol})$, and proper benzyl chloride was added $(11 \mathrm{mmol})$. The reaction mixture was stirred with a magnetic stirrer for $3 \mathrm{~h}$ at ambient temperature. Then the white solid was filtered off and washed with methanol $(10 \mathrm{~mL})$ and water $(10 \mathrm{~mL})$ and then dried at atmospheric pressure. Its purity was monitored by TLC using chloroform as eluent. 
Ethyl 4-(benzylsulfanyl)-6-methyl-2-phenylpyrimidine-5-carboxylate (2a). Product characterization: yield, $3.03 \mathrm{~g}$, 83.24\%; white solid; melting point, $100-101{ }^{\circ} \mathrm{C}$; ${ }^{1} \mathrm{HNMR}(300 \mathrm{MHz}$, $\left.\mathrm{CDCl}_{3}\right): \delta(\mathrm{ppm}), 1.44\left(3 \mathrm{H}, \mathrm{t}, \mathrm{CH}_{3}\right), 2.68\left(3 \mathrm{H}, \mathrm{s}, \mathrm{CH}_{3}\right), 4.45\left(2 \mathrm{H}, \mathrm{q}, \mathrm{CH}_{2}\right), 4.63\left(2 \mathrm{H}, \mathrm{s}, \mathrm{CH}_{2}\right)$, 7.24-8.52 (10H, m, aromatic). MS (ESI) $m / z[\mathrm{M}+\mathrm{H}]^{+} 365.1293$, calcd. $m / z$ 365.1318. FTIR (ATR, selected lines): $v\left(\mathrm{~cm}^{-1}\right) 651(\mathrm{C}-\mathrm{S}), 1686(\mathrm{C}=\mathrm{O})$.

Ethyl 4-methyl-6-\{[(2-methylphenyl)methyl]sulfanyl\}-2-phenylpyrimidine-5-carboxylate (2b) Product characterization: yield, $3.11 \mathrm{~g}, 82.28 \%$; white solid; melting point, $105-106{ }^{\circ} \mathrm{C}$; ${ }^{1} \mathrm{HNMR}$ (300 MHz, DMSO-d 6 ): $\delta(\mathrm{ppm}), 1.30$ (3H, t, CH3), 2.36 (3H, s, CH3), 2.57 (3H, s, CH3), 4.34 (2H, q, CH2), 4.62 (2H, s, CH2), 7.11-8.46 (9H, m, aromatic). MS (ESI) $m / z[\mathrm{M}+\mathrm{H}]^{+}$ 379.1447, calcd. $m / z$ 379.1474. FTIR (ATR, selected lines): $v\left(\mathrm{~cm}^{-1}\right) 651(\mathrm{C}-\mathrm{S}), 1698(\mathrm{C}=\mathrm{O})$.

\subsubsection{Preparation of Compounds $\mathbf{2} \mathbf{c}$ and $\mathbf{2} \mathbf{d}-\mathbf{2} \mathbf{j}$}

Ethyl 4-amino-6-methyl-2-phenylpyrimidine-5-carboxylate (2c)

Ethyl 4-hydroxy-6-methyl-2-phenylpyrimidine-5-carboxylate (1b) (2.58 g, 10 mmol) [16] was placed in a round bottom flask, and $10 \mathrm{~mL}$ of $\mathrm{POCl}_{3}$ was added. The mixture was refluxed for $3 \mathrm{~h}$, poured slowly into $100 \mathrm{~mL}$ of icy water, and extracted three times with $25 \mathrm{~mL}$ of $\mathrm{CHCl}_{3}$. The extracts were combined, dried with anhydrous $\mathrm{MgSO}_{4}$ for $30 \mathrm{~min}$, and concentrated with a rotary evaporator. Then the solution of the crude product in $10 \mathrm{~mL}$ of THF was saturated with ammonia for $3 \mathrm{~h}$, then poured into $100 \mathrm{~mL}$ of $2 \% \mathrm{HCl}$ and extracted three times with $25 \mathrm{~mL}$ of $\mathrm{CHCl}_{3}$. The extracts were combined and dried with $5 \mathrm{~g}$ of anhydrous $\mathrm{MgSO}_{4}$ for $30 \mathrm{~min}$. The drying agent was filtered off, and the solvent was removed with a rotary evaporator. The crude product was purified by column chromatography on silica gel using $\mathrm{CHCl}_{3}$ as eluent and dried at atmospheric pressure. The purity of the product was verified by TLC using chloroform as eluent.

Product characterization: yield, $2.30 \mathrm{~g}, 89.15 \%$; beige solid; melting point, $127{ }^{\circ} \mathrm{C}$; ${ }^{1} \mathrm{HNMR}\left(300 \mathrm{MHz}, \mathrm{CDCl}_{3}\right): \delta(\mathrm{ppm}), 1.43\left(3 \mathrm{H}, \mathrm{t}, \mathrm{CH}_{3}\right), 2.80\left(3 \mathrm{H}, \mathrm{s}, \mathrm{CH}_{3}\right), 4.41\left(2 \mathrm{H}, \mathrm{q}, \mathrm{CH}_{2}\right)$, 7.46-8.45 (5H, m, aromatic). MS (ESI) $m / z[\mathrm{M}+\mathrm{H}]^{+} 258.1253$, calcd. $m / z$ 258.1237. FTIR (ATR, selected lines): $v\left(\mathrm{~cm}^{-1}\right) 1674(\mathrm{C}=\mathrm{O}), 3263\left(\mathrm{NH}_{2}\right), 3187\left(\mathrm{NH}_{2}\right)$.

Other methods for obtaining the compound were also reported [17].

\subsubsection{General Procedure for the Preparation of $\mathbf{2} \mathbf{d}-\mathbf{2} \mathbf{j}$}

Ethyl 4-hydroxy-6-methyl-2-phenylpyrimidine-5-carboxylate (1b) (2.58 g, 10 mmol) [16] was placed in a round bottom flask, and $10 \mathrm{~mL}$ of $\mathrm{POCl}_{3}$ was added. The mixture was refluxed for $3 \mathrm{~h}$, poured slowly into $100 \mathrm{~mL}$ of icy water, and extracted three times with $25 \mathrm{~mL}$ of $\mathrm{CHCl}_{3}$. The extracts were combined, dried with anhydrous $\mathrm{MgSO}_{4}$ for $30 \mathrm{~min}$, and concentrated with a rotary evaporator. Then the crude product was dissolved in a mixture of $10 \mathrm{~mL}$ of methanol and $5 \mathrm{~mL}$ of triethylamine, and an appropriate substituted primary alkyl amine $(12 \mathrm{mmol})$ was added. The reaction mixture was stirred at room temperature for $24 \mathrm{~h}$. After this time, the precipitate was filtered off, washed with $5 \mathrm{~mL}$ of cold methanol, and dried at atmospheric pressure. The crude product was purified by column chromatography on silica gel using chloroform as eluent. The purity of the product was verified by TLC using chloroform as eluent.

Ethyl 4-(ethylamino)-6-methyl-2-phenylpyrimidine-5-carboxylate (2d). Product characterization: yield, $2.08 \mathrm{~g}$, 72.73\%; white solid; melting point, $54-55{ }^{\circ} \mathrm{C} ;{ }^{1} \mathrm{HNMR}\left(300 \mathrm{MHz}, \mathrm{CDCl}_{3}\right): \delta$ (ppm), $1.34\left(3 \mathrm{H}, \mathrm{t}, \mathrm{CH}_{3}\right), 1.44\left(3 \mathrm{H}, \mathrm{t}, \mathrm{CH}_{3}\right), 2.75\left(3 \mathrm{H}, \mathrm{s}, \mathrm{CH}_{3}\right), 3.66-3.76\left(2 \mathrm{H}, \mathrm{m}, \mathrm{CH}_{2}\right), 4.40$ $\left(2 \mathrm{H}, \mathrm{q}, \mathrm{CH}_{2}\right), 7.46-8.51\left(5 \mathrm{H}, \mathrm{m}\right.$, aromatic). MS (ESI) $m / z[\mathrm{M}+\mathrm{H}]^{+} 286.1598$, calcd. $m / z$ 286.1550. FTIR (ATR, selected lines): $v\left(\mathrm{~cm}^{-1}\right) 1670(\mathrm{C}=\mathrm{O}), 3327(\mathrm{NH})$.

Ethyl 4-methyl-2-phenyl-6-(propylamino)pyrimidine-5-carboxylate (2e). Product characterization: yield, $2.06 \mathrm{~g}$, 68.67\%; white solid; melting point, $45^{\circ} \mathrm{C} ;{ }^{1} \mathrm{HNMR}\left(300 \mathrm{MHz}, \mathrm{CDCl}_{3}\right): \delta$ (ppm), $1.03\left(3 \mathrm{H}, \mathrm{t}, \mathrm{CH}_{3}\right), 1.42\left(3 \mathrm{H}, \mathrm{t}, \mathrm{CH}_{3}\right), 1.72\left(2 \mathrm{H}, \mathrm{sx}, \mathrm{CH}_{2}\right), 2.75\left(3 \mathrm{H}, \mathrm{s}, \mathrm{CH}_{3}\right), 3.63(2 \mathrm{H}$, q, $\left.\mathrm{CH}_{2}\right), 4.39\left(2 \mathrm{H}, \mathrm{q}, \mathrm{CH}_{2}\right), 7.46-8.49\left(5 \mathrm{H}, \mathrm{m}\right.$, aromatic). MS (ESI) $m / z[\mathrm{M}+\mathrm{H}]^{+} 300.1726$, calcd. $m / z$ 300.1707. FTIR (ATR, selected lines): $v\left(\mathrm{~cm}^{-1}\right) 1674(\mathrm{C}=\mathrm{O}), 3327(\mathrm{NH})$. 
Ethyl 4-methyl-2-phenyl-6-[(prop-2-en-1-yl)amino]pyrimidine-5-carboxylate (2f). Product characterization: yield, $1.99 \mathrm{~g}, 66.68 \%$; white solid; melting point, $82-83{ }^{\circ} \mathrm{C} ;{ }^{1} \mathrm{HNMR}(300 \mathrm{MHz}$, $\left.\mathrm{CDCl}_{3}\right): \delta(\mathrm{ppm}), 1.44\left(3 \mathrm{H}, \mathrm{t}, \mathrm{CH}_{3}\right), 3.21\left(3 \mathrm{H}, \mathrm{s}, \mathrm{CH}_{3}\right), 4.38\left(2 \mathrm{H}, \mathrm{t}, \mathrm{CH}_{2}\right), 4.46\left(2 \mathrm{H}, \mathrm{q}, \mathrm{CH}_{2}\right)$, $5.30\left(2 \mathrm{H}, \mathrm{t}, \mathrm{CH}_{2}\right), 5.92-6.05(1 \mathrm{H}, \mathrm{m}, \mathrm{CH}), 7.53-8.67(5 \mathrm{H}, \mathrm{m}$, aromatic). MS (ESI) $\mathrm{m} / \mathrm{z}$ [M $+\mathrm{H}^{+}$298.1530, calcd. $m / z$ 298.1550. FTIR (ATR, selected lines): $v\left(\mathrm{~cm}^{-1}\right) 1666(\mathrm{C}=\mathrm{O})$, $3299(\mathrm{NH})$.

Ethyl 4-methyl-2-phenyl-6-[(propan-2-yl)amino]pyrimidine-5-carboxylate (2g). Product characterization: yield, $2.17 \mathrm{~g}$, 72.33\%; white solid; melting point, $108-109{ }^{\circ} \mathrm{C} ;{ }^{1} \mathrm{HNMR}(300 \mathrm{MHz}$, $\left.\mathrm{CDCl}_{3}\right): \delta(\mathrm{ppm}), 1.34\left(6 \mathrm{H}, \mathrm{d}, 2 \mathrm{CH}_{3}\right), 1.44\left(3 \mathrm{H}, \mathrm{t}, \mathrm{CH}_{3}\right), 2.74\left(3 \mathrm{H}, \mathrm{s}, \mathrm{CH}_{3}\right), 4.39\left(2 \mathrm{H}, \mathrm{t}, \mathrm{CH}_{2}\right)$, $4.58(1 \mathrm{H}, \mathrm{sx}, \mathrm{CH}), 7.47-8.49\left(5 \mathrm{H}, \mathrm{m}\right.$, aromatic), $8.21\left(1 \mathrm{H}\right.$, broad, NH). MS (ESI) $m / z[\mathrm{M}+\mathrm{H}]^{+}$ 300.1711, calcd. $m / z$ 300.1707. FTIR (ATR, selected lines): $v\left(\mathrm{~cm}^{-1}\right) 1674(\mathrm{C}=\mathrm{O}), 3299(\mathrm{NH})$.

Ethyl 4-(tert-butylamino)-6-methyl-2-phenylpyrimidine-5-carboxylate (2h). Product characterization: yield, $2.43 \mathrm{~g}$, 77.39\%; white solid; melting point, $103{ }^{\circ} \mathrm{C} ;{ }^{1} \mathrm{HNMR}\left(300 \mathrm{MHz}, \mathrm{CDCl}_{3}\right): \delta$ (ppm), $1.42\left(3 \mathrm{H}, \mathrm{t}, \mathrm{CH}_{3}\right), 1.58\left(9 \mathrm{H}, \mathrm{s}, 3 \mathrm{xCH}_{3}\right), 2.71\left(3 \mathrm{H}, \mathrm{s}, \mathrm{CH}_{3}\right), 4.37\left(2 \mathrm{H}, \mathrm{q}, \mathrm{CH}_{2}\right), 7.46-8.47$ (5H, $\mathrm{m}$, aromatic). MS (ESI) $m / z[\mathrm{M}+\mathrm{H}]^{+} 314.1836$, calcd. $m / z$ 314.1863. FTIR (ATR, selected lines): $v\left(\mathrm{~cm}^{-1}\right) 1666(\mathrm{C}=\mathrm{O}), 3287(\mathrm{NH})$.

Ethyl 4-[(2-hydroxyethyl)amino]-6-methyl-2-phenylpyrimidine-5-carboxylate (2i). Product characterization: yield, $2.25 \mathrm{~g}$, 74.50\%; white solid; melting point, $76-77^{\circ} \mathrm{C}$; ${ }^{1} \mathrm{HNMR}(300 \mathrm{MHz}$, $\left.\mathrm{CDCl}_{3}\right): \delta(\mathrm{ppm}), 1.44\left(3 \mathrm{H}, \mathrm{t}, \mathrm{CH}_{3}\right), 2.77\left(3 \mathrm{H}, \mathrm{s}, \mathrm{CH}_{3}\right), 3.82-3.93\left(4 \mathrm{H}, \mathrm{m}, \mathrm{CH}_{2}-\mathrm{CH}_{2}\right) 4.40$ $\left(2 \mathrm{H}, \mathrm{q}, \mathrm{CH}_{2}\right), 7.47-8.44\left(5 \mathrm{H}, \mathrm{m}\right.$, aromatic), $8.73\left(1 \mathrm{H}, \mathrm{s}\right.$, broad, NH). MS (ESI) $m / z[\mathrm{M}+\mathrm{H}]^{+}$ 302.1482, calcd. $m / z$ 302.1499. FTIR (ATR, selected lines): $v\left(\mathrm{~cm}^{-1}\right) 1678(\mathrm{C}=\mathrm{O}), 3319(\mathrm{NH})$.

Ethyl 4-(cyclohexylamino)-6-methyl-2-phenylpyrimidine-5-carboxylate (2j). Product characterization: yield, $2.01 \mathrm{~g}$, 59.12\%; white solid; melting point, $72-73{ }^{\circ} \mathrm{C}$; ${ }^{1} \mathrm{HNMR}(300 \mathrm{MHz}$, $\left.\mathrm{CDCl}_{3}\right): \delta(\mathrm{ppm}), 1.25-2.15\left(10 \mathrm{H}, \mathrm{m}, 5 \mathrm{xCH} \mathrm{CH}_{2}\right.$, cykloheksyl; $\left.3 \mathrm{H}, \mathrm{t}, \mathrm{CH}_{3}\right), 2.77\left(3 \mathrm{H}, \mathrm{t}, \mathrm{CH}_{3}\right)$, $4.30(1 \mathrm{H}, \mathrm{m}, \mathrm{CH}), 4.40\left(2 \mathrm{H}, \mathrm{q}, \mathrm{CH}_{2}\right), 7.46-7.52(3 \mathrm{H}, \mathrm{m}$, aromatic), $8.40(1 \mathrm{H}$, broad, $\mathrm{NH})$, 8.45-8.49 (2H, m, aromatic). MS (ESI) $m / z[\mathrm{M}+\mathrm{H}]^{+} 340.2053$, calcd. $m / z$ 340.2020. FTIR (ATR, selected lines): $v\left(\mathrm{~cm}^{-1}\right) 1670(\mathrm{C}=\mathrm{O}), 3307(\mathrm{NH})$.

\subsubsection{General Procedure for the Preparation of $\mathbf{3 a}-\mathbf{3 h}$}

First, $2 \mathrm{mmol}$ of proper ester 2 was dissolved in $20 \mathrm{~mL}$ of THF. Then, the mixture was cooled to $0^{\circ} \mathrm{C}$, and $\mathrm{LiAlH}_{4}(0.19 \mathrm{~g}, 5 \mathrm{mmol})$ was added gradually in small quantities. After $1 \mathrm{~h}, 25 \mathrm{~mL}$ of $\mathrm{CHCl}_{3}$ was added; then the mixture was poured into the icy water $(100 \mathrm{~mL})$ and extracted three times with $\mathrm{CHCl}_{3}(50 \mathrm{~mL})$. The extracts were combined and dried with $2 \mathrm{~g}$ of anhydrous $\mathrm{MgSO}_{4}$ for $30 \mathrm{~min}$. The drying agent was filtered off, and the solvent was removed with a rotary evaporator. The crude product was crystallized from methanol. The purity of the product was monitored by TLC using a mixture of chloroform and ethyl ether $(3: 1 ; v / v)$ as eluent.

[4-(benzylsulfanyl)-6-methyl-2-phenylpyrimidin-5-yl]methanol (3a). Product characterization: yield, $0.45 \mathrm{~g}$, 70.04\%; white solid; melting point, $144-145{ }^{\circ} \mathrm{C} ;{ }^{1} \mathrm{HNMR}\left(300 \mathrm{MHz}, \mathrm{CDCl}_{3}\right): \delta$ (ppm), $2.76\left(3 \mathrm{H}, \mathrm{s}, \mathrm{CH}_{3}\right), 4.64\left(2 \mathrm{H}, \mathrm{s}, \mathrm{CH}_{2}\right), 4.79\left(2 \mathrm{H}, \mathrm{s}, \mathrm{CH}_{2}\right), 7.28-8.54(10 \mathrm{H}, \mathrm{m}$, aromatic). MS (ESI) $m / z[\mathrm{M}+\mathrm{H}]^{+} 323.1189$, calcd. $m / z$ 323.1213. FTIR (ATR, selected lines): $v\left(\mathrm{~cm}^{-1}\right.$ ) 639 (C-S), $3374(\mathrm{OH})$.

(4-methyl-6-\{[(2-methylphenyl)methyl]sulfanyl\}-2-phenylpyrimidin-5-yl)methanol (3b). Product characterization: yield, $0.49 \mathrm{~g}, 72.44 \%$; white solid; melting point, $147{ }^{\circ} \mathrm{C} ;{ }^{1} \mathrm{HNMR}$ $\left(300 \mathrm{MHz}, \mathrm{CDCl}_{3}\right): \delta(\mathrm{ppm}), 2.44\left(3 \mathrm{H}, \mathrm{s}, \mathrm{CH}_{3}\right), 2.65\left(3 \mathrm{H}, \mathrm{s}, \mathrm{CH}_{3}\right), 4.67\left(2 \mathrm{H}, \mathrm{s}, \mathrm{CH}_{2}\right), 4.77(2 \mathrm{H}$, $\left.\mathrm{s}, \mathrm{CH}_{2}\right), 7.10-8.52\left(9 \mathrm{H}, \mathrm{m}\right.$, aromatic). MS (ESI) $m / z[\mathrm{M}+\mathrm{H}]^{+} 337.1343$, calcd. $m / z$ 337.1369. FTIR (ATR, selected lines): $v\left(\mathrm{~cm}^{-1}\right) 635(\mathrm{C}-\mathrm{S}), 3343(\mathrm{OH})$.

(4-amino-6-methyl-2-phenylpyrimidin-5-yl)methanol (3c). Product characterization: yield, $0.31 \mathrm{~g}, 72.09 \%$; white solid; melting point, $177-178{ }^{\circ} \mathrm{C} ;{ }^{1} \mathrm{HNMR}\left(300 \mathrm{MHz}, \mathrm{DMSO}-\mathrm{d}_{6}\right): \delta$ (ppm), $2.40\left(3 \mathrm{H}, \mathrm{s}, \mathrm{CH}_{3}\right), 4.47\left(2 \mathrm{H}, \mathrm{d}, \mathrm{CH}_{2}\right), 4.93(1 \mathrm{H}, \mathrm{t}, \mathrm{OH}), 6.58\left(2 \mathrm{H}, \mathrm{s}\right.$, broad, $\left.\mathrm{NH}_{2}\right)$, 
7.41-8.30 (5H, m, aromatic). MS (ESI) $m / z[\mathrm{M}+\mathrm{H}]^{+} 216.1110$, calcd. $m / z$ 216.1131. FTIR (ATR, selected lines): $v\left(\mathrm{~cm}^{-1}\right) 3183(\mathrm{OH}), 3311\left(\mathrm{NH}_{2}\right), 3418\left(\mathrm{NH}_{2}\right)$.

[4-(ethylamino)-6-methyl-2-phenylpyrimidin-5-yl]methanol (3d). Product characterization: yield, $0.42 \mathrm{~g}$, 85.71\%; white solid; melting point, $191{ }^{\circ} \mathrm{C}$; ${ }^{1} \mathrm{HNMR}(300 \mathrm{MHz}$, DMSO$\left.\mathrm{d}_{6}\right): \delta(\mathrm{ppm}), 1.22\left(3 \mathrm{H}, \mathrm{t}, \mathrm{CH}_{3}\right), 2.39\left(3 \mathrm{H}, \mathrm{s}, \mathrm{CH}_{3}\right), 3.54\left(2 \mathrm{H}, \mathrm{q}, \mathrm{CH}_{2}\right), 4.49\left(2 \mathrm{H}, \mathrm{d}, \mathrm{CH}_{2}\right), 5.00$ $(1 \mathrm{H}, \mathrm{t}, \mathrm{OH}), 6.77(1 \mathrm{H}$, broad, $\mathrm{NH}), 7.43-8.36\left(5 \mathrm{H}, \mathrm{m}\right.$, aromatic). MS (ESI) $m / z[\mathrm{M}+\mathrm{H}]^{+}$ 244.1458, calcd. $m / z$ 244.1444. FTIR (ATR, selected lines): $v\left(\mathrm{~cm}^{-1}\right) 3239(\mathrm{OH}$, broad), $3366(\mathrm{NH})$.

[4-methyl-2-phenyl-6-(propylamino)pyrimidin-5-yl]methanol (3e). Product characterization: yield, $0.39 \mathrm{~g}$, 76.47\%; white solid; melting point, $158-159{ }^{\circ} \mathrm{C} ;{ }^{1} \mathrm{HNMR}\left(300 \mathrm{MHz}, \mathrm{DMSO}-\mathrm{d}_{6}\right)$ : $\delta(\mathrm{ppm}), 0.94\left(3 \mathrm{H}, \mathrm{t}, \mathrm{CH}_{3}\right), 1.64\left(2 \mathrm{H}, \mathrm{sx}, \mathrm{CH}_{2}\right), 2.38\left(3 \mathrm{H}, 3.47\left(2 \mathrm{H}, \mathrm{q}, \mathrm{CH}_{2}\right), 4.50\left(2 \mathrm{H}, \mathrm{d}, \mathrm{CH}_{2}\right)\right.$, $5.03(1 \mathrm{H}, \mathrm{t}, \mathrm{OH}), 6.77\left(1 \mathrm{H}\right.$, broad, NH), $7.43-8.35(5 \mathrm{H}, \mathrm{m}$, aromatic $)$ MS (ESI) $m / z[\mathrm{M}+\mathrm{H}]^{+}$ 258.1566 calcd. $m / z$ 258.1601. FTIR (ATR, selected lines): $v\left(\mathrm{~cm}^{-1}\right) 3263(\mathrm{OH}), 3414(\mathrm{NH})$.

\{4-methyl-2-phenyl-6-[(prop-2-en-1-yl)amino]pyrimidin-5-yl\}methanol (3f). Product characterization: yield, $0.37 \mathrm{~g}$, 72.55\%; white solid; melting point, $174-175{ }^{\circ} \mathrm{C}$; ${ }^{1} \mathrm{HNMR}(300 \mathrm{MHz}$, $\left.\mathrm{DMSO}_{-} \mathrm{d}_{6}\right): \delta(\mathrm{ppm}), 2.40\left(3 \mathrm{H}, \mathrm{s}, \mathrm{CH}_{3}\right), 4.16\left(2 \mathrm{H}, \mathrm{t}, \mathrm{CH}_{2}\right), 4.52\left(2 \mathrm{H}, \mathrm{d}, \mathrm{CH}_{2}\right), 5.03-5.27(3 \mathrm{H}$, $\left.\mathrm{m}, \mathrm{CH}_{2} ; \mathrm{OH}\right), 5.94-6.07(1 \mathrm{H}, \mathrm{m}, \mathrm{CH}), 6.94(1 \mathrm{H}, \mathrm{t}, \mathrm{NH}), 7.43-8.33(5 \mathrm{H}, \mathrm{m}$, aromatic). MS (ESI) $m / z[\mathrm{M}+\mathrm{H}]^{+} 256.1402$, calcd. $m / z$ 256.1444. FTIR (ATR, selected lines): $v\left(\mathrm{~cm}^{-1}\right.$ ) $3259(\mathrm{OH}$, broad), $3347(\mathrm{NH})$.

\{4-methyl-2-phenyl-6-[(propan-2-yl)amino]pyrimidin-5-yl\}methanol (3g). Product characterization: yield, $0.40 \mathrm{~g}$, 78.43\%; white solid; melting point, $160{ }^{\circ} \mathrm{C}$; ${ }^{1} \mathrm{HNMR}(300 \mathrm{MHz}$, DMSO-d 6 ): $\delta$ (ppm), $1.25\left(6 \mathrm{H}, \mathrm{d}, 2 \mathrm{xCH}_{3}\right), 2.38\left(3 \mathrm{H}, \mathrm{s}, \mathrm{CH}_{3}\right), 4.42(1 \mathrm{H}, \mathrm{sx}, \mathrm{CH}), 4.50(2 \mathrm{H}$, $\left.\mathrm{d}, \mathrm{CH}_{2}\right), 5.09(1 \mathrm{H}, \mathrm{t}, \mathrm{OH}), 6.42(1 \mathrm{H}, \mathrm{d}, \mathrm{NH}), 7.43-8.34(5 \mathrm{H}, \mathrm{m}$, aromatic $)$. MS (ESI) $\mathrm{m} / z$ $[\mathrm{M}+\mathrm{H}]^{+}$258.1605, calcd. $m / z$ 258.1601. FTIR (ATR, selected lines): $v\left(\mathrm{~cm}^{-1}\right) 3215(\mathrm{OH})$, $3386(\mathrm{NH})$.

[4-(tert-butylamino)-6-methyl-2-phenylpyrimidin-5-yl]methanol (3h). Product characterization: yield, $0.37 \mathrm{~g}$, 68.52\%; white solid; melting point, $173-174{ }^{\circ} \mathrm{C} ;{ }^{1} \mathrm{HNMR}\left(300 \mathrm{MHz}, \mathrm{DMSO}-\mathrm{d}_{6}\right)$ : $\delta(\mathrm{ppm}), 1.52\left(9 \mathrm{H}, \mathrm{s}, 3 \times \mathrm{CH}_{3}\right), 2.36\left(3 \mathrm{H}, \mathrm{s}, \mathrm{CH}_{3}\right), 4.50\left(2 \mathrm{H}, \mathrm{d}, \mathrm{CH}_{2}\right), 5.31(1 \mathrm{H}, \mathrm{t}, \mathrm{OH}), 6.31(1 \mathrm{H}$, $\mathrm{s}, \mathrm{NH}), 7.45-8.33\left(5 \mathrm{H}, \mathrm{m}\right.$, aromatic). MS (ESI) $m / z[\mathrm{M}+\mathrm{H}]^{+} 272.1722$, calcd. $m / z 272.1757$. FTIR (ATR, selected lines): $v\left(\mathrm{~cm}^{-1}\right) 3124(\mathrm{OH}), 3331(\mathrm{NH})$.

2-\{[5-(hydroxymethyl)-6-methyl-2-phenylpyrimidin-4-yl]amino\}ethan-1-ol (3i). Product characterization: yield, $0.44 \mathrm{~g}$, 83.72\%; white solid; melting point, $141{ }^{\circ} \mathrm{C} ;{ }^{1} \mathrm{HNMR}(300 \mathrm{MHz}$, DMSO-d $\left.)_{6}\right): \delta(\mathrm{ppm}), 2.40\left(3 \mathrm{H}, \mathrm{s}, \mathrm{CH}_{3}\right), 3.55-3.69\left(4 \mathrm{H}, \mathrm{m}, \mathrm{CH}_{2}-\mathrm{CH}_{2}\right), 4.50\left(2 \mathrm{H}, \mathrm{d}, \mathrm{CH}_{2}\right), 4.79$ $(1 \mathrm{H}, \mathrm{t}, \mathrm{OH}), 5.07(1 \mathrm{H}, \mathrm{t}, \mathrm{OH}), 6.82(1 \mathrm{H}, \mathrm{s}$, broad, $\mathrm{NH}), 7.44-8.36(5 \mathrm{H}, \mathrm{m}$, aromatic). MS (ESI) $m / z[\mathrm{M}+\mathrm{H}]^{+}$260.1392, calcd. $m / z$ 260.1394. FTIR (ATR, selected lines): $v\left(\mathrm{~cm}^{-1}\right) 3147$ $(\mathrm{OH}$, broad).

[4-(cyclohexylamino)-6-methyl-2-phenylpyrimidin-5-yl]methanol (3j). Product characterization: yield, $0.49 \mathrm{~g}$, 83.05\%; white solid; melting point, $143{ }^{\circ} \mathrm{C} ;{ }^{1} \mathrm{HNMR}\left(300 \mathrm{MHz}, \mathrm{DMSO}-\mathrm{d}_{6}\right): \delta$ (ppm), 1.17-2.04 (10H, m, 5xCH $\left.\mathrm{CH}_{2}\right), 2.38\left(3 \mathrm{H}, \mathrm{s}, \mathrm{CH}_{3}\right), 4.10(1 \mathrm{H}, \mathrm{s}, \mathrm{CH}), 4.52\left(2 \mathrm{H}, \mathrm{d}, \mathrm{CH}_{2}\right)$, $5.17(1 \mathrm{H}, \mathrm{t}, \mathrm{OH}), 6.47(1 \mathrm{H}, \mathrm{d}, \mathrm{NH}), 7.40-8.40\left(5 \mathrm{H}, \mathrm{m}\right.$, aromatic). MS (ESI) $m / z[\mathrm{M}+\mathrm{H}]^{+}$ 298.1924, calcd. $m / z$ 298.1914. FTIR (ATR, selected lines): $v\left(\mathrm{~cm}^{-1}\right) 3243(\mathrm{OH}), 3362(\mathrm{NH})$.

\subsection{X-ray Structural Studies}

Compounds $3 \mathrm{c}$ and $\mathbf{3 e}-\mathbf{3 h}$ were dissolved in hot methanol or acetone, and their crystals were obtained by slow evaporation of the solvent at room temperature. Crystals suitable for X-ray diffraction analysis appeared after 1-5 days. Single-crystal X-ray diffraction data were collected with Mo-K $\alpha(\lambda=0.71073 \AA)$ (for $3 \mathbf{c}, 3 \mathbf{e}$, and $3 \mathbf{g}-3 \mathbf{h})$ or Cu-K $\alpha(\lambda=1.5418 \AA)$ (for $3 f$ ) radiations and $\omega$-scan modes using automated four-circle diffractometers with CCD detectors: Kuma KM4 (for $\mathbf{3 c}$ and $\mathbf{3 h}$ ), Xcalibur R (for $3 \mathbf{e}$ and $\mathbf{3 g}$ ), and Xcalibur PX (for 3f). The data were measured at 200(2) K (for 3c) or 100(2) K (for 3e-3h) using an Oxford Cryosystems open-flow nitrogen cryostat. This paper provides the selected 
crystallographic data and structure refinements for compounds $\mathbf{3 c}$ and $\mathbf{3 e}-\mathbf{3 h}$ in Table S1 in Supplementary Materials. The CrysAlisPro software package [18] was used for data collection, cell refinement, data reduction, and analysis. The data of $\mathbf{3 f}$ were corrected for absorption by the analytical method. The crystal structures were solved by direct methods using SHELXS-97 [19] and refined by a full-matrix least-squares technique on $\mathrm{F}^{2}$ with SHELXL-2013 (and further also with SHELXL-2018) [20]. All non-H atoms were refined with anisotropic displacement parameters. During the refinement for $3 \mathbf{h}$, one of two crystallographically independent molecules exhibited disorder over two positions related by a pseudo mirror plane (denoted as B and C) and was refined in the same site occupation factors of 0.5. SAME instruction was used in the refinement procedure equal to the restrained geometrical parameters of the disordered molecule of $3 \mathrm{~h}$ (equivalent bond distances and angles). Additionally, two C41C and C43C atoms were constrained with EADP instruction and refined with the same fractional coordinates. All $\mathrm{H}$ atoms were initially found in the difference Fourier maps and refined isotropically. In the final refinement cycles, they were included from the geometry of the molecules and refined isotropically using a riding model, with $\mathrm{C}-\mathrm{H}=0.95-0.99 \AA$ and $\mathrm{U}_{\text {iso }}(\mathrm{H})=1.2 \mathrm{U}_{\text {eq }}(\mathrm{C})$ for $\mathrm{CH}$ and $\mathrm{CH}_{2}$ or $\mathrm{U}_{\text {iso }}(\mathrm{H})=1.5 \mathrm{U}_{\text {eq }}(\mathrm{C})$ for $\mathrm{CH}_{3}, \mathrm{~N}-\mathrm{H}=0.88 \AA$ and $\mathrm{O}-\mathrm{H}=0.84 \AA$, and $\mathrm{U}_{\mathrm{iso}}(\mathrm{H})=1.2 \mathrm{U}_{\mathrm{eq}}(\mathrm{N})$ and $1.5 \mathrm{U}_{\mathrm{eq}}(\mathrm{O})$, respectively. All figures were prepared using the DIAMOND program [21]. Analysis of the intra- and intermolecular interactions was performed using the PLATON program [22].

The supplementary crystallographic data for this article (CCDC 2102842-2102846) were deposited in the Cambridge Crystallographic Data Centre at www.ccdc.cam.ac.uk/ data_request/cif (accessed on 8 November 2021) and can be obtained free of charge, by e-mailing data_request@ccdc.cam.ac.uk, or by contacting the Cambridge Crystallographic Data Centre, 12 Union Road, Cambridge CB2 1EZ, UK (fax: +44(0)1223-336033).

\subsection{Biological Activity Assays}

\subsubsection{Chemicals}

All reagents for cell culture, unless otherwise stated, were purchased from Merck (Darmstadt, Germany). Stock solutions were made 100x concentrated in pure DMSO (dimethyl sulfoxide) (Chempur, Poland) and freshly diluted in appropriate complete cell culture medium on the experiment day. Cell cultures were acquired from the European Collection of Authenticated Cell Cultures (ECACC). Reagents for microbiology assays were purchased from Oxoid (Basingstoke, UK).

\subsubsection{Cell Culture}

For cytotoxicity assays, the following cell lines were used: human renal proximal tubule epithelial cells (RPTEC-MTOX1030), epithelioid cervix carcinoma (HeLa-93021013), colon adenocarcinoma (Caco-2-86010202), hepatocarcinoma (HepaRG-MTOX1010), gastric adenocarcinoma (AGS-89090402), and glioblastoma (A172-88062428) cells were cultured in appropriate media according to the European Collection of Authenticated Cell Cultures (ECACC) recommendation. To all media (except for RPTEC), $2.5 \mu \mathrm{g} \mathrm{mL}^{-1}$ amphotericin B, $100 \mathrm{U} \mathrm{mL}^{-1}$ penicillin, and $100 \mu \mathrm{g} \mathrm{mL}^{-1}$ streptomycin were added. In addition, the RPTEC cell line was cultured in media with $30 \mu \mathrm{g} \mathrm{mL}^{-1}$ gentamicin and $15 \mathrm{ng} \mathrm{mL}^{-1}$ amphotericin B. Cell cultures were incubated at $37^{\circ} \mathrm{C}$ in a humidified atmosphere with $5 \% \mathrm{CO}_{2}$ for at least three passages until performing experiments. All cell lines were grown in monolayers; thus, detachment with $0.25 \%$ trypsin solution was required for further assays.

\subsubsection{Neutral Red Uptake Assay}

The cells were put in 96-well plates $(1 \times 105$ cells per $\mathrm{mL})$ of appropriate culture medium $(100 \mu \mathrm{L}$ per well). Before a general experiment, cells were attached for $24 \mathrm{~h}$ and then treated with various concentrations $(500,250,100$, and $10 \mu \mathrm{M})$ of pyrimidine derivatives and subsequently grown in $200 \mu \mathrm{L}$ medium volume. Controls with $1 \%$ DMSO, culture medium, and $1 \mu \mathrm{M}$ staurosporine were running simultaneously with the pyrimidine- 
derivatives-treated cultures. The cells were incubated for 24,48 , and $72 \mathrm{~h}$ at $37{ }^{\circ} \mathrm{C}$ in a humidified $5 \% \mathrm{CO}_{2} / 95 \%$ air incubator. The neutral red uptake assay was performed according to Repetto et al. [23]. This method uses the ability of the living cells to accumulate dye in their lysosomes. Briefly, at the end of each incubation time the cells were treated with neutral red solution $\left(40 \mu \mathrm{g} \mathrm{mL}{ }^{-1}\right)$ for $2 \mathrm{~h}$ at $37^{\circ} \mathrm{C}$. Afterwards, the cells were washed with PBS, and the incorporated dye was solubilized with the extraction solution (50\% ethanol, $49 \% \mathrm{H}_{2} \mathrm{O}, 1 \%$ glacial acetic acid). The plates were gently shaken for $30 \mathrm{~min}$ at $37{ }^{\circ} \mathrm{C}$. Finally, the absorbance was measured at $540 \mathrm{~nm}$ using a Thermo Scientific ${ }^{\mathrm{TM}}$ Multiskan ${ }^{\mathrm{TM}} \mathrm{GO}$ Microplate Spectrophotometer (Thermo Fisher).

\subsubsection{Microbiology}

Antimicrobial activity assays were performed on seven reference strains obtained from ATCC collection (Acinetobacter baumannii, Candida albicans, Enterococcus faecalis, Escherichia coli, Klebsiella pneumoniae, Pseudomonas aeruginosa, methicillin-resistant Staphylococcus aureus (MRSA)). Microorganisms were propagated on Tryptone Soy Agar (TSA) plates. Bacteria were incubated at $37^{\circ} \mathrm{C}$, and Candida albicans was incubated at $25^{\circ} \mathrm{C}$. After $24 \mathrm{~h}$ incubation, microorganisms were diluted in Tryptone Soy Broth (TSB) (bacteria to $0.005 \mathrm{MF}$ and C. albicans to $0.025 \mathrm{MF}$ ) and seeded on 96-well plates, which already contained tested compounds at final concentrations from $256 \mu \mathrm{g} \mathrm{mL}^{-1}$ to $0.5 \mu \mathrm{g} \mathrm{mL}^{-1}$. Every plate included controls: TSB with strain, TSB with strain and solvent (1\% DMSO), and TSB with strain and appropriate antibiotic. Microplates were incubated on a horizontal shaker at $500 \mathrm{rpm}$ in $37 \pm 1^{\circ} \mathrm{C}$ for $24 \mathrm{~h}$, and absorbance was measured by a microplate reader at $580 \mathrm{~nm}$ using the Thermo Scientific ${ }^{\mathrm{TM}}$ Multiskan ${ }^{\mathrm{TM}}$ GO Microplate Spectrophotometer (Thermo Fisher). Subsequently, $50 \mu \mathrm{L}$ aliquots of $5 \mu \mathrm{L}$ of $1 \%$ aqueous solution of 2,3,5-triphenyltetrazolium chloride (TTC) were added to each well to check the viability of microorganisms. Plates were inspected visually for color change after $24 \mathrm{~h}$ incubation.

\subsubsection{Statistical Analysis}

The viability tests were conducted in quadruple wells $(n=4)$ for each condition. Values are presented as mean \pm standard deviation (SD). Significant differences were calculated using one-way ANOVA, followed by post hoc comparison, and the half-maximal inhibitory concentration (IC50) was obtained by nonlinear regression using GraphPad Prism 9.1 for Windows, GraphPad Software, La Jolla, California, USA, www.graphpad.com. A $p$-value $<0.05$ was considered statistically significant. All results were compared with the control with $1 \%$ DMSO, which was considered to be $100 \%$.

\subsection{In Silico Analysis}

For the analysis, compounds $\mathbf{3 a}, \mathbf{3 h}$, and $\mathbf{3 g}$ were chosen due to their half-maximal inhibitory concentration (IC50) measured after $72 \mathrm{~h}$ incubation with cancerous cell lines.

\subsubsection{ADME Analysis}

ADME analysis of compounds $\mathbf{3 a}, \mathbf{3 g}$, and $\mathbf{3 h}$ was performed via SwissADME [24], a freely available software provided by the Swiss Institute of Bioinformatics. The software provides information about estimated predictors, such as basic physiochemical properties, lipophilicity, water solubility, pharmacokinetics, druglikeness, and medicinal chemistry (Table 4). Physiochemical properties are relevant due to crossing biological barriers. Lipophilicity is very important for pharmacokinetics drug discovery. Orally active drugs should consist of no more than 5 hydrogen bond donors less than 10 hydrogen bond acceptors, molecular weight of less than 500 daltons, and an n-octanol and water partition coefficient lesser than 5 [25]. Water solubility is connected to the oral admission of the drug. Water solubility is the major property of medicine absorption. Being a substrate of the permeability glycoprotein is a predictor of pharmacokinetics. Knowledge about the interaction of the compound and cytochromes $\mathrm{P} 450$ gives information about effective drug elimination 
through metabolic biotransformation. The last predictor-medicinal chemistry-supports structural drug discovery. It informs about problematic structural fragments inside the investigated compound.

\subsubsection{Molecular Docking Analysis}

Estimation of probable macromolecular targets was performed using SwissTargetPrediction [26], choosing Homo sapiens as a target species. SwissTargetPrediction is a freely available web tool provided by the Swiss Bioinformatics Institute.

The protein target structures listed above were downloaded from the Protein Data Bank (PDB). The inhibitors from the complexes were removed, as well as water molecules. The $\mathrm{pH}$ value for the protonation of both the ligand (compounds $3 \mathrm{a}, 3 \mathrm{~g}$, and $3 \mathbf{h}$ ) and the protein was set to 7.4 using PDB2PQR [27]. The input files were prepared using AutoDock tools [28]. The search space of each protein was defined from "center on hetero". A box was placed on the geometric center of an existing ligand. The molecular docking was performed using AutoDock Vina [29]. The docking was performed for each target from the Table 5. presented in Section 3.4.

\section{Results}

\subsection{Chemistry}

The substrates $\mathbf{1 a}$ and $\mathbf{1} \mathbf{b}$ were prepared as described previously $[15,16]$. The benzylsulfanyl esters $\mathbf{2} \mathbf{a}$ and $\mathbf{2} \mathbf{b}$ were obtained using the method exploited in our previous publication (Figure 2) [14]. In short, substrate 1a was dissolved in a methanolic solution of $\mathrm{NaOH}$ and coupled with appropriate benzyl chloride. The precipitate of ester was washed and dried at atmospheric pressure.

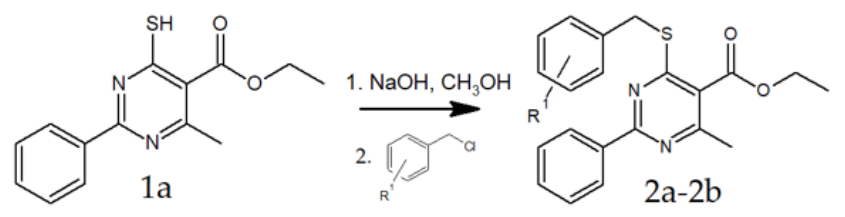

\begin{tabular}{|c|c|}
\hline Compound & $\mathbf{R}^{1}$ \\
\hline $2 \mathrm{a}$ & $\mathrm{H}$ \\
\hline $2 \mathrm{~b}$ & $2-\mathrm{CH}_{3}$ \\
\hline
\end{tabular}

Figure 2. Synthetic routes of preparing compounds $\mathbf{2} \mathbf{a}$ and $\mathbf{2 b}$.

Aminoesters were obtained by the reaction of the product of chlorination of the substrate $1 \mathrm{~b}$ with gaseous ammonia in THF (2c) or proper alkyl amines in the mixture of trimethylamine and methanol (2-2-2j) (Figure 3) and purified via column chromatography using $\mathrm{CHCl}_{3}$ as eluent.

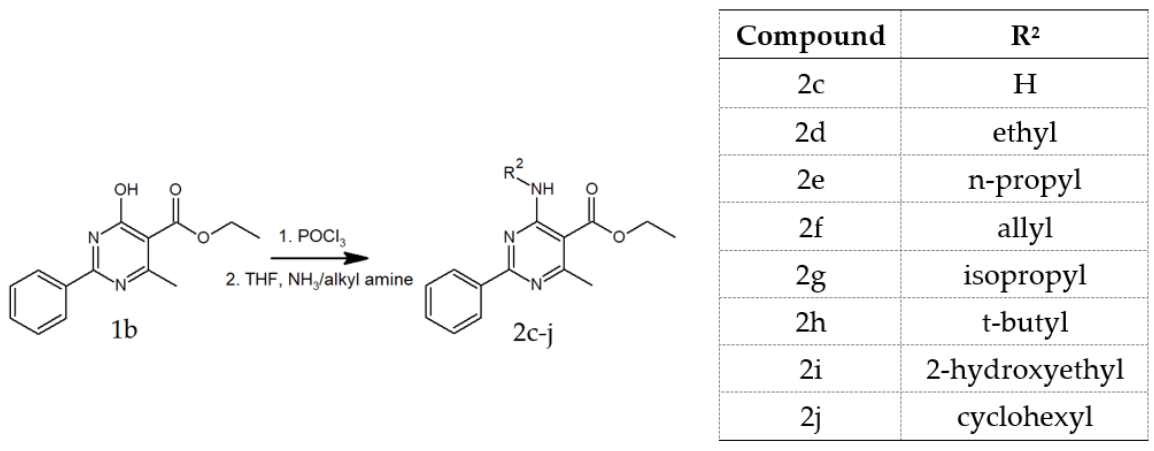

Figure 3. Synthetic routes of preparing compounds $\mathbf{2} \mathbf{c}-\mathbf{2 j}$.

Final products $\mathbf{3 a} \mathbf{a} \mathbf{3} \mathbf{j}$ were obtained by reduction of esters $\mathbf{2} \mathbf{a}-\mathbf{2} \mathbf{j}$ with $\mathrm{LiAlH}_{4}$ in THF (Figure 4 ) and purified by column chromatography (3a and $\mathbf{3} \mathbf{b}$ ) or crystallization (3c-3j). 


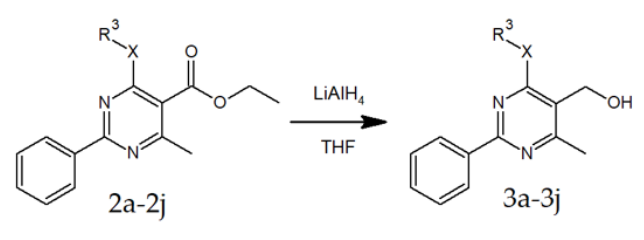

\begin{tabular}{|c|c|c|}
\hline Compound & $\mathbf{X}$ & $\mathbf{R}^{3}$ \\
\hline $2 \mathrm{a}, 3 \mathrm{a}$ & $\mathrm{S}$ & benzyl \\
\hline $2 \mathrm{~b}, 3 \mathrm{~b}$ & $\mathrm{~S}$ & 2-CH3-benzyl \\
\hline $2 \mathrm{c}, 3 \mathrm{c}$ & $\mathrm{NH}$ & $\mathrm{H}$ \\
\hline $2 \mathrm{~d}, 3 \mathrm{~d}$ & $\mathrm{NH}$ & ethyl \\
\hline $2 \mathrm{e}, 3 \mathrm{e}$ & $\mathrm{NH}$ & n-propyl \\
\hline $2 \mathrm{f}, 3 \mathrm{f}$ & $\mathrm{NH}$ & allyl \\
\hline $2 \mathrm{~g}, 3 \mathrm{~g}$ & $\mathrm{NH}$ & isopropyl \\
\hline $2 \mathrm{~h}, 3 \mathrm{~h}$ & $\mathrm{NH}$ & t-butyl \\
\hline $2 \mathrm{i}, 3 \mathrm{i}$ & $\mathrm{NH}$ & 2-hydroxyethyl \\
\hline $2 \mathrm{j}, 3 \mathrm{j}$ & $\mathrm{NH}$ & cyclohexyl \\
\hline
\end{tabular}

Figure 4. Synthetic route of preparing compounds $3 \mathbf{a}-\mathbf{3} \mathbf{j}$.

Using the presented set of reactions, we obtained a series of various 5-hydroxymethylpyrimidines that vary at the 4-position. Structural variations of the compounds were applied to draw conclusions about the structure-activity relationship.

\subsection{Crystal Structures of Compounds $3 \mathbf{c}$ and $\mathbf{3 e}-\mathbf{3 h}$}

Compounds $3 \mathbf{c}$ and $\mathbf{3 e}-\mathbf{3 g}$ crystallize in a common $P 2_{1} / c$ space group of the monoclinic system with $Z=4$ and one crystallographically independent molecule in the asymmetric unit (Figure $5 \mathrm{a}-\mathrm{d}$ ). In contrast to them, it was found that compound $3 \mathrm{~h}$ crystallizes in the noncentrosymmetric orthorhombic $P c a 2_{1}$ space group, with $Z=8$, and comprises two crystallographically independent molecules in the asymmetric unit, one ordered molecule (denoted as A) (Figure 5e) and a second disordered molecule over two positions being related by a pseudo mirror plane (hereafter referred to as B and C). Selected crystallographic data and structure refinements are presented in Table S1, and comparison of selected geometrical parameters for compounds $\mathbf{3} \mathbf{c}$ and $\mathbf{3 e}-\mathbf{3} \mathbf{h}$ are tabulated in Table S2, Supplementary Materials of this paper.

All molecules of compounds $3 \mathbf{c}$ and $3 \mathbf{e}-3 \mathbf{h}$ contain the same 5-hydroxymethyl-2phenylpyrimidine core and vary at the 4-position, in particular containing amino (3c), propylamino (3e), allylamino (3f), isopropylamino (3g), and tert-butylamino (3g) groups. All molecules have a conformation with the planar pyrimidine ring (with rms. deviation range of $0.008-0.020 \AA$ ) and the substituent in the 2-position twisted relative to it by 26.4 $(2)^{\circ}$ in $3 \mathbf{c}, 9.5(2)^{\circ}$ in $3 \mathbf{e}, 10.9(2)^{\circ}$ in $3 \mathbf{f}, 15.7(2)^{\circ}$ in $3 \mathbf{g}$, and 18.5-20.6 (2) ${ }^{\circ}$ in $3 \mathbf{h}$, respectively. In cases of secondary amines, the heterocyclic N3 atom and the C41 atom of the amino group are nearly located on the same side of the molecule, as shown by the N3-C4-N4-C41 torsion angle $\left(-6.8(2)^{\circ}, 17.1(2)^{\circ}, 0.4(2)^{\circ}\right.$, and $-12(3)^{\circ}$ in $3 \mathbf{e}, \mathbf{3 f}, \mathbf{3 g}$, and $\mathbf{3 h}$ (see Table S2, Supplementary Materials of this paper). The hydroxyl moiety $[\mathrm{O}(\mathrm{H})-\mathrm{C}=1.418-1.441 \AA]$ is in a gauche conformation with respect to the pyrimidine $\mathrm{C} 4$ atom, which is reflected by the values of the O1-C51-C5-C4 torsion angle of $-53.9(2)^{\circ}, 63.3(2)^{\circ}, 64.5(2)^{\circ},-62.9(2)^{\circ}$, and $49.0(6)^{\circ}$ (or $50(2)^{\circ}$ and $\left.49(2)^{\circ}\right)$ for $\mathbf{3 c}, \mathbf{3 e}, \mathbf{3 f}, \mathbf{3 g}$, and the molecule A (or in the positions $\mathrm{B}$ and $\mathrm{C}$ of the second molecule) of $3 \mathrm{~h}$, respectively. Except for $3 \mathrm{f}$, the orientation of the amino and hydroxyl groups to each other is stabilized by the intramolecular $\mathrm{N} 4-\mathrm{H} \cdots \mathrm{O} 1$ hydrogen bond (see Table 1), which closes a six-membered ring with S(6) motif [30]. 


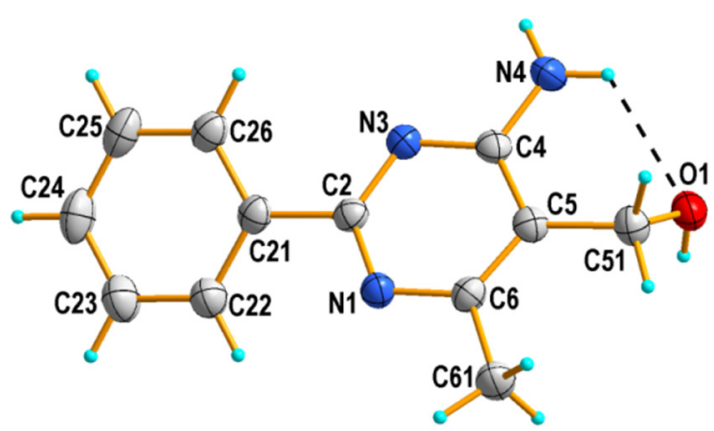

(a)

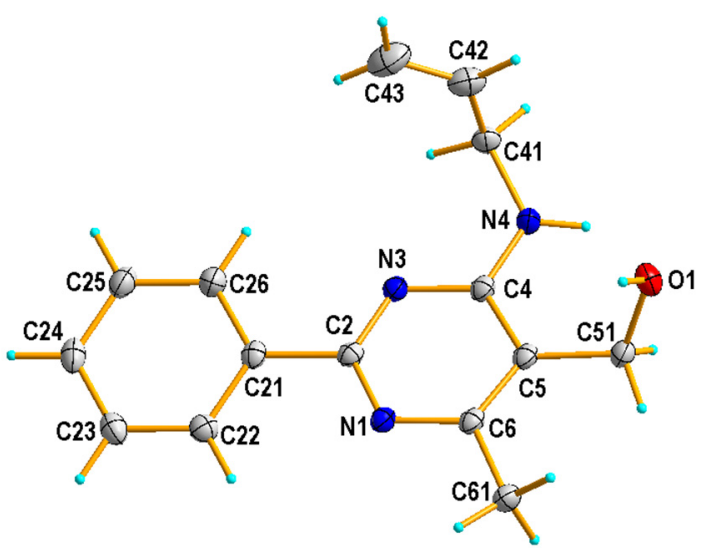

(c)

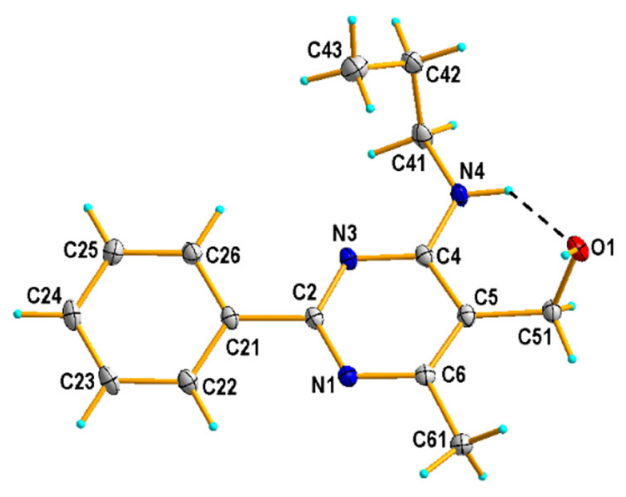

(b)

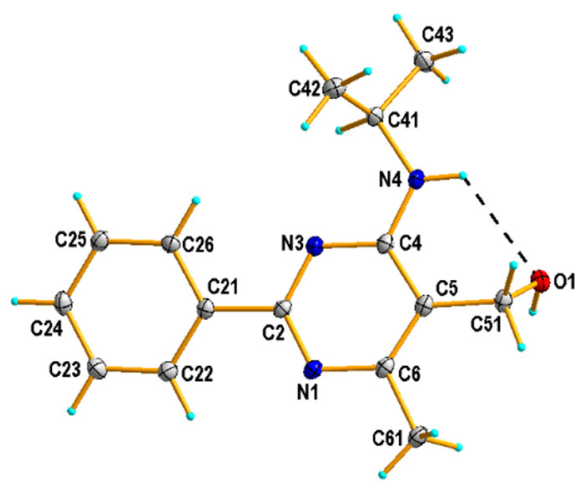

(d)

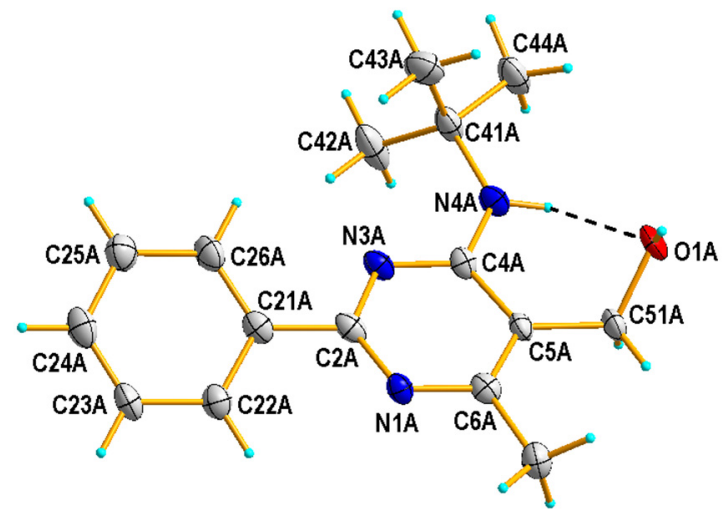

(e)

Figure 5. X-ray structures of $3 \mathbf{c}(\mathbf{a}), 3 \mathbf{e}(\mathbf{b}), 3 \mathbf{f}(\mathbf{c})$, and $3 \mathbf{g}(\mathbf{d})$ and one of two crystallographically independent molecules (denoted as A) of $3 \mathbf{h}$ (e) (displacement ellipsoids at 50\% probability level), with an atom-numbering scheme. Dashed lines (in black) show intramolecular $\mathrm{N}-\mathrm{H} \cdots \mathrm{O}$ hydrogen bonds forming $\mathrm{S}(6)$ motifs.

In the crystal structures, except for $3 \mathrm{f}$, each molecule is connected via $\mathrm{O}-\mathrm{H} \cdots \mathrm{N}$ hydrogen bonds (Table 1), between the hydroxyl O1 (as donors) and the pyrimidine $\mathrm{N} 1$ atoms (as acceptors), to form a C(6) chain along the c-axis. Representative one-dimensional chains formed through intermolecular $\mathrm{O}-\mathrm{H} \cdots \mathrm{N}$ interactions in the crystal structures of $\mathbf{3 c}$ and $\mathbf{3 g}$ are presented in Figure 6. In case of $3 \mathbf{f}$, such $\mathrm{O}-\mathrm{H} \cdots \mathrm{N}$ hydrogen bond interactions lead to the formation of a dimer. These dimers interact further via intermolecular $\mathrm{N}-\mathrm{H} \cdots \mathrm{O}$ hydrogen bonds, between the amine $\mathrm{N} 4$ (as donors) and the hydroxyl $\mathrm{O} 1$ atoms (as acceptors), resulting in a ribbon of molecules running along the c-axis direction (Figure 7). In $3 \mathbf{c}$, a 
2D hydrogen-bonded network is created by the connection of neighboring chains through $\mathrm{N}-\mathrm{H} \cdots \mathrm{N}$ hydrogen-bonding interactions, involving the amine $\mathrm{N} 4$ (as donors) and the pyrimidine N3 atoms (as acceptors) (see Figure S61). In all cases, the crystal structures are stabilized by weak $\mathrm{C}-\mathrm{H} \cdots \pi$ and also aromatic $\pi-\pi$ stacking interactions. In turn, for $\mathbf{3 g}$, additional stabilization is also provided by weak $\mathrm{C}-\mathrm{H} \cdots \mathrm{O}$ hydrogen bonding interactions, involving the isopropyl (as donors) and hydroxyl (as acceptors) groups (Table 1).

Table 1. Geometry of intra- and intermolecular hydrogen bonds for compounds $3 \mathbf{c}$ and $3 \mathbf{e}-3 \mathbf{h}$.

\begin{tabular}{|c|c|c|c|c|c|}
\hline Compounds & D-H $\cdots A$ & D-H & $\mathbf{H} \cdots \mathbf{A}$ & $\mathrm{D} \cdots \mathrm{A}$ & D-H $\cdots A$ \\
\hline \multirow{4}{*}{$3 c$} & $\mathrm{O} 1-\mathrm{H} 1 \cdots \mathrm{N} 1^{\mathrm{i}}$ & 0.84 & 2.01 & $2.825(2)$ & 162 \\
\hline & $\mathrm{N} 4-\mathrm{H} 41 \cdots \mathrm{N} 3{ }^{\mathrm{ii}}$ & 0.88 & 2.31 & $3.151(2)$ & 159 \\
\hline & 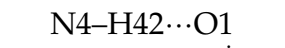 & 0.88 & 2.29 & $2.834(2)$ & 120 \\
\hline & $\mathrm{O} 1-\mathrm{H} 1 \cdots \mathrm{N} 1{ }^{\mathrm{i}}$ & 0.84 & 2.13 & $2.9525(14)$ & 165 \\
\hline \multirow[t]{2}{*}{$3 e$} & $\mathrm{~N} 4-\mathrm{H} 4 \cdots \mathrm{O} 1{ }^{\mathrm{ii}}$ & 0.88 & 2.48 & $3.1361(14)$ & 132 \\
\hline & $\mathrm{N} 4-\mathrm{H} 4 \cdots \mathrm{O} 1$ & 0.88 & 2.41 & $3.0116(13)$ & 126 \\
\hline \multirow{2}{*}{$3 f$} & $\mathrm{O} 1-\mathrm{H} 1 \cdots \mathrm{N} 1{ }^{\mathrm{i}}$ & 0.84 & 2.09 & $2.9199(16)$ & 172 \\
\hline & $\mathrm{N} 4-\mathrm{H} 4 \cdots \mathrm{O} 1$ ii & 0.88 & 2.13 & $2.9434(16)$ & 154 \\
\hline \multirow{4}{*}{$3 g$} & $\mathrm{O} 1-\mathrm{H} 1 \cdots \mathrm{N} 1^{\mathrm{i}}$ & 0.84 & 2.08 & 2.9009 (12) & 164 \\
\hline & $\mathrm{N} 4-\mathrm{H} 4 \cdots \mathrm{O} 1$ ii & 0.88 & 2.50 & $3.3210(13)$ & 155 \\
\hline & N4-H4 ‥ 1 & 0.88 & 2.55 & 3.0577 (14) & 118 \\
\hline & $\mathrm{C} 43-\mathrm{H} 431 \cdots \mathrm{O} 1 \mathrm{ii}$ & 0.98 & 2.62 & $3.4038(16)$ & 138 \\
\hline \multirow{6}{*}{$3 h$} & O1A-H1A $\cdots \mathrm{N} \mathrm{A}^{\mathrm{i}}$ & 0.84 & 1.97 & $2.772(5)$ & 159 \\
\hline & N4A-H4A $\cdots \mathrm{O} 1 \mathrm{~A}$ & 0.88 & 2.18 & $2.767(5)$ & 124 \\
\hline & O1B-H1B $\cdots$ N1C ${ }^{\text {ii }}$ & 0.84 & 2.01 & $2.78(2)$ & 152 \\
\hline & 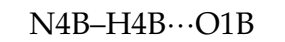 & 0.88 & 2.21 & $2.773(16)$ & 122 \\
\hline & $\mathrm{O} 1 \mathrm{C}-\mathrm{H} 1 \mathrm{C} \cdots \mathrm{N} 1 \mathrm{~B}$ & 0.84 & 1.95 & $2.77(2)$ & 163 \\
\hline & $\mathrm{N} 4 \mathrm{C}-\mathrm{H} 4 \mathrm{C} \cdots \mathrm{O} 1 \mathrm{C}$ & 0.88 & 2.20 & $2.78(3)$ & 123 \\
\hline
\end{tabular}

Symmetry codes: $3 c$ : (i) $x,-y+3 / 2, z-1 / 2 ;$ (ii) $-x+1,-y+1,-z ; 3 e:(i)-x,-y+1,-z+1 ;($ ii) $-x,-y+1$ $-\mathrm{z}$; 3f: (i) $-\mathrm{x}+1,-\mathrm{y}+1,-\mathrm{z}+1$; (ii) $-\mathrm{x}+1,-\mathrm{y}+1,-\mathrm{z}+2$; 3g: (i) $\mathrm{x},-\mathrm{y}+3 / 2, \mathrm{z}-1 / 2$; (ii) $-\mathrm{x},-\mathrm{y}+1,-\mathrm{z}$; $3 \mathrm{~h}$ : $-x+1 / 2, y, z+1 / 2 ;-x,-y+1, z-1 / 2$.

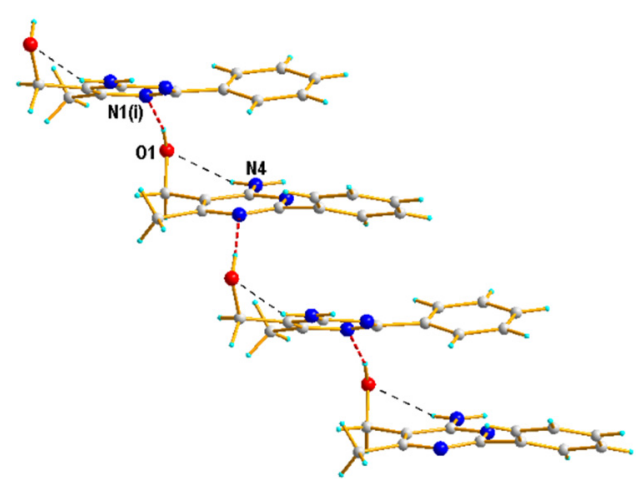

(a)

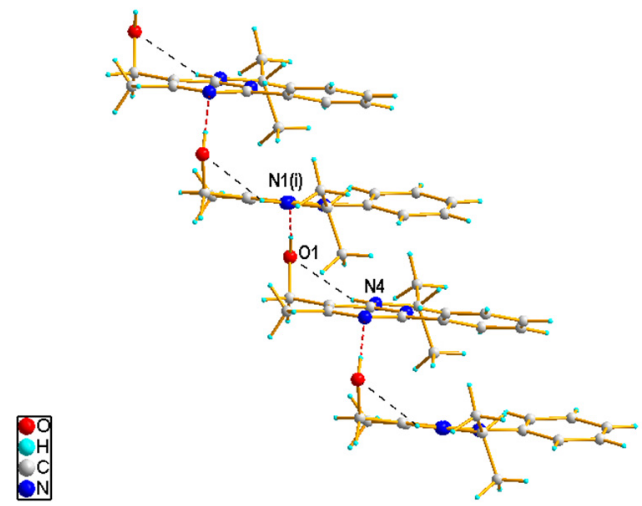

(b)

Figure 6. Part of the crystal structures of $3 \mathbf{c}(\mathbf{a})$ and $3 g(b)$, showing the formation of the one-dimensional chain through $\mathrm{O}-\mathrm{H} \cdots \mathrm{N}$ (in red) intermolecular interactions. Dashed lines (in black) indicate intramolecular $\mathrm{N}-\mathrm{H} \cdots \mathrm{O}$ hydrogen bonds. The symmetry codes are as in Table 1. 


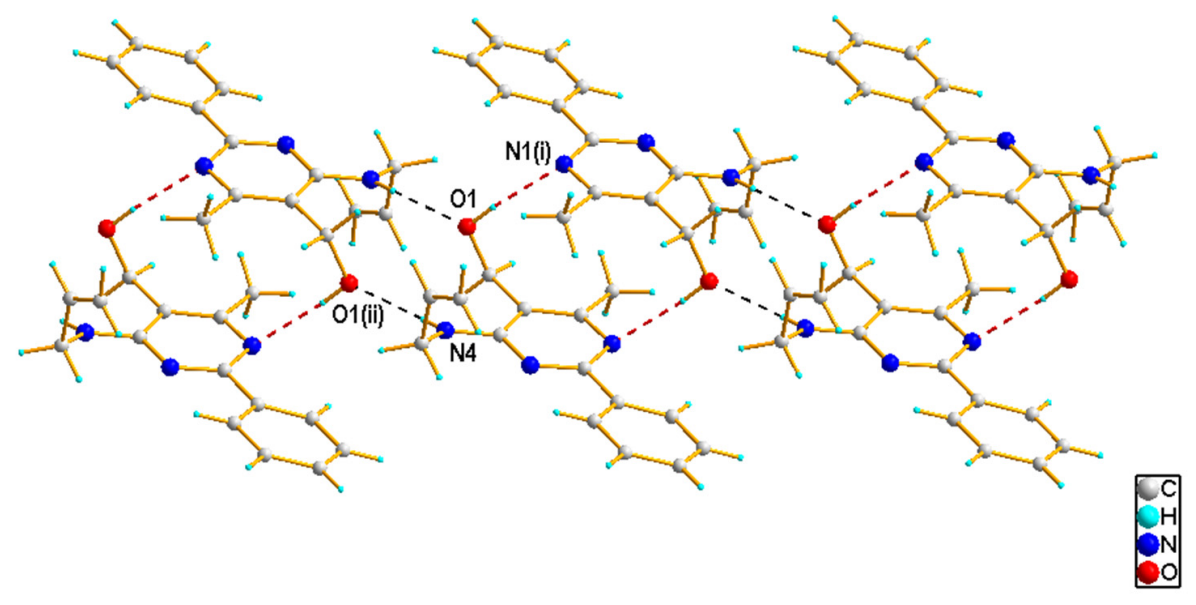

Figure 7. Part of the crystal structure of $\mathbf{3 f}$, showing the formation of the ribbon through intermolecular interactions, with $\mathrm{O}-\mathrm{H} \cdots \mathrm{N}$ in red and $\mathrm{N}-\mathrm{H} \cdots \mathrm{O}$ in black. The symmetry codes are as in Table 1.

\subsection{Biological Activity Analysis}

\subsubsection{Cytotoxic and Antiproliferative Effect}

Ten pyrimidine derivatives, $\mathbf{3} \mathbf{a}-\mathbf{3} \mathbf{j}$, were tested for the cytotoxic properties on the RPTEC cell line with the neutral red uptake assay. Results are shown in Figure 8. Compounds $3 \mathbf{b}(500 \mu \mathrm{M}=34 \%, 250 \mu \mathrm{M}=46 \%, 100 \mu \mathrm{M}=44 \%, 10 \mu \mathrm{M}=91 \%)$ and $\mathbf{3 j}$ $(500 \mu \mathrm{M}=16 \%, 250 \mu \mathrm{M}=70 \%, 100 \mu \mathrm{M}=28 \%, 10 \mu \mathrm{M}=89 \%)$ decreased the cell viability at lower concentrations ( 100 and $10 \mu \mathrm{M})$ and, therefore, were excluded from further analysis on cancerous cell lines and microorganisms.

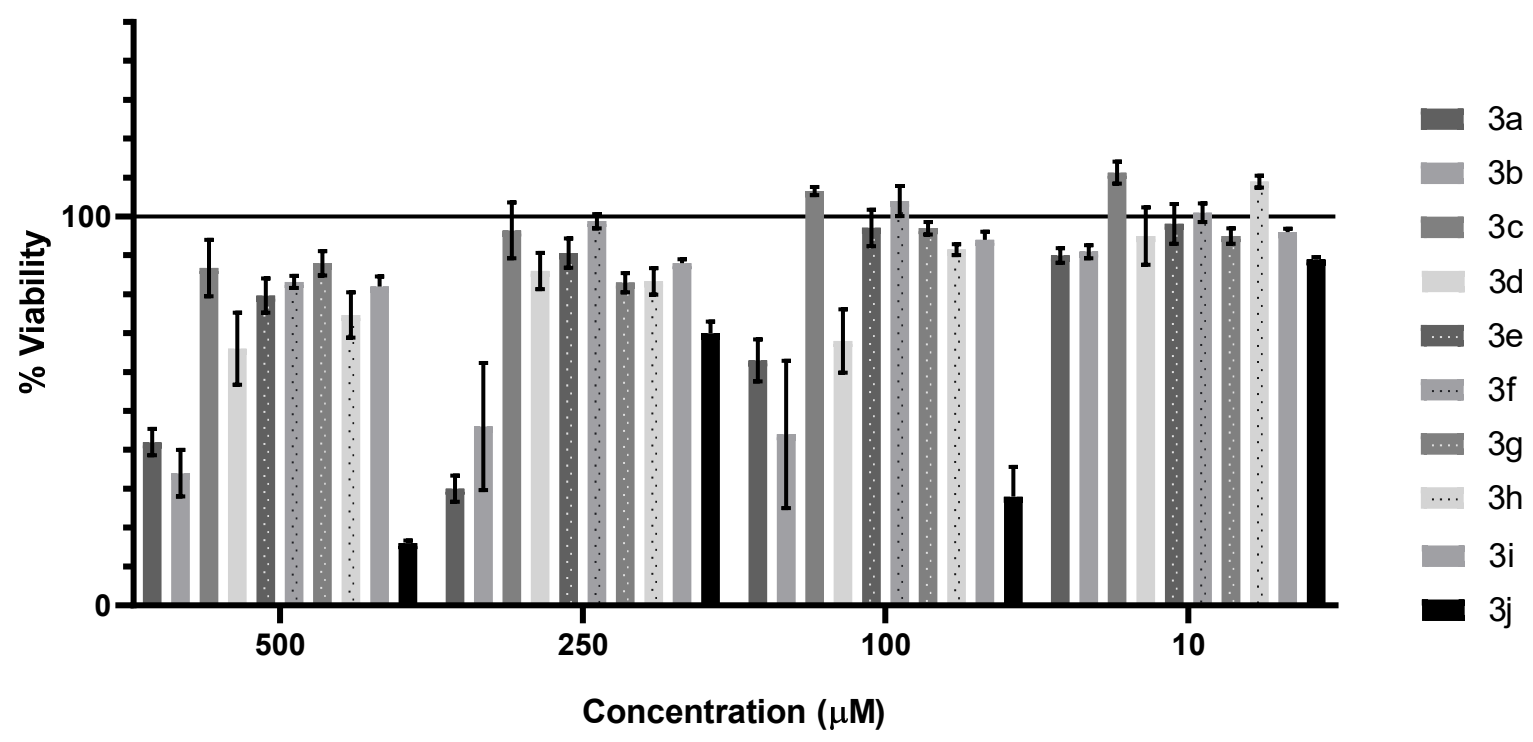

Figure 8. Viability of RPTEC cell line after $72 \mathrm{~h}$ treatment with tested compounds.

In further research, pyrimidine derivatives were tested for their anticancer activity. Compounds in a wide concentration range (10-250 $\mu \mathrm{M})$ were applied on cells. Viability and proliferative abilities were tested with the neutral red uptake assay and assessed by comparing with the control with solvent (1\% DMSO). Calculated IC50 values for all tested compounds are presented in Table 2. The highest cytotoxic properties were found after HepaRG treatment with $3 \mathbf{h}(132.3 \mu \mathrm{M})$. This cell line was found to be the most susceptible for tested compounds, as three from eight pyrimidine derivatives decreased cell viability to the sufficient level to calculate IC50. 
Table 2. IC50 $(\mu \mathrm{M})$ of tested compounds after $72 \mathrm{~h}$ incubation with cancerous cell lines, obtained in the neutral red uptake assay.

\begin{tabular}{cccccc}
\hline & HeLa & HepaRG & Caco-2 & AGS & A172 \\
\hline 3a & $>250 \mu \mathrm{M}$ & $200.8 \mu \mathrm{M}$ & $>250 \mu \mathrm{M}$ & $209.2 \mu \mathrm{M}$ & $>250 \mu \mathrm{M}$ \\
3c & $>250 \mu \mathrm{M}$ & $>250 \mu \mathrm{M}$ & $>250 \mu \mathrm{M}$ & $>250 \mu \mathrm{M}$ & $>250 \mu \mathrm{M}$ \\
3d & $>250 \mu \mathrm{M}$ & $>250 \mu \mathrm{M}$ & $>250 \mu \mathrm{M}$ & $>250 \mu \mathrm{M}$ & $>250 \mu \mathrm{M}$ \\
3e & $>250 \mu \mathrm{M}$ & $>250 \mu \mathrm{M}$ & $>250 \mu \mathrm{M}$ & $>250 \mu \mathrm{M}$ & $>250 \mu \mathrm{M}$ \\
3f & $>250 \mu \mathrm{M}$ & $>250 \mu \mathrm{M}$ & $>250 \mu \mathrm{M}$ & $>250 \mu \mathrm{M}$ & $>250 \mu \mathrm{M}$ \\
3g & $209.4 \mu \mathrm{M}$ & $183.3 \mu \mathrm{M}$ & $>250 \mu \mathrm{M}$ & $>250 \mu \mathrm{M}$ & $146.7 \mu \mathrm{M}$ \\
$\mathbf{3 h}$ & $>250 \mu \mathrm{M}$ & $132.3 \mu \mathrm{M}$ & $>250 \mu \mathrm{M}$ & $>250 \mu \mathrm{M}$ & $>250 \mu \mathrm{M}$ \\
3i & $>250 \mu \mathrm{M}$ & $>250 \mu \mathrm{M}$ & $>250 \mu \mathrm{M}$ & $>250 \mu \mathrm{M}$ & $>250 \mu \mathrm{M}$ \\
Staurosporine & $1 \mu \mathrm{M}$ & $1 \mu \mathrm{M}$ & $1 \mu \mathrm{M}$ & $1 \mu \mathrm{M}$ & $1 \mu \mathrm{M}$ \\
\hline
\end{tabular}

\subsubsection{Antimicrobial Activity}

The antimicrobial activities of tested pyrimidine derivatives are presented in Table 3 as minimal inhibitory concentration (MIC). MICs were determined for A. baumannii (3e, $3 \mathrm{~g}$, and $3 \mathrm{~h}=256 \mu \mathrm{g} / \mathrm{mL})$, C. albicans $(3 \mathbf{a}=256 \mu \mathrm{g} / \mathrm{mL})$, E. coli $(3 \mathrm{~g}=128 \mu \mathrm{g} / \mathrm{mL}), E$. faecalis $(3 \mathbf{e}=256 \mu \mathrm{g} / \mathrm{mL})$, and MRSA $(3 \mathbf{f}=256 \mu \mathrm{g} / \mathrm{mL})$. Treatment with TTC indicated no MBC/MFC activity.

Table 3. MIC $\left(\mu \mathrm{g} \mathrm{mL}^{-1}\right)$ of compounds tested against a panel of microorganisms.

\begin{tabular}{|c|c|c|c|c|c|c|c|c|c|}
\hline & $3 a$ & $3 c$ & $3 d$ & $3 e$ & $3 f$ & $3 g$ & $3 h$ & $3 \mathbf{i}$ & $\begin{array}{c}\text { Standard Agent } \\
(\mu \mathrm{g} / \mathrm{mL})\end{array}$ \\
\hline A. baumannii & - & - & - & 256 & - & 256 & 256 & - & Levofloxacin: 0.5 \\
\hline P. aeruginosa & - & - & - & - & - & - & - & - & Levofloxacin: 1 \\
\hline E. coli & - & - & - & - & & 128 & - & - & Gentamicin: 2 \\
\hline E. faecalis & - & - & - & 256 & - & - & - & - & Levofloxacin: 4 \\
\hline K. pneumoniae & - & - & - & - & - & - & - & - & Gentamicin: 2 \\
\hline$M R S A$ & - & - & - & - & 256 & - & - & - & Levofloxacin: 1 \\
\hline C. albicans & 256 & - & - & - & - & - & - & - & Amphotericin B: 1 \\
\hline
\end{tabular}

\subsection{In Silico Studies}

\subsubsection{ADME Analysis}

For the in silico analysis, compounds $\mathbf{3 a}, \mathbf{3 h}$, and $\mathbf{3 g}$ were chosen due to their preferable IC50 measured after $72 \mathrm{~h}$ incubation with cancer cell lines. ADME analysis was performed regarding six predictors pointed in 2.4.1 [24]. In Table 4, specific details for the chosen compound are presented.

Table 4. ADME analysis results.

$3 \mathbf{a}$

The compound has a molecular weight of $308.40 \mathrm{~g} / \mathrm{mol}$; number of heavy atoms and number of aromatic heavy atoms: 22 and

11 , respectively; number of rotatable bonds: 4 ; number of

Physiochemical properties
H-bond acceptors and donors: 3

and 1 , respectively. The value of the polar surface area (PSA)

calculated using the topological polar surface area (TPSA), considering sulfur and phosphorus as polar atoms, is $71.32 \AA^{2}$ [31].
$3 g$

The compound has a molecular weight of $257.33 \mathrm{~g} / \mathrm{mol}$; number of heavy atoms and number of aromatic heavy atoms: 19 and 12 , respectively; number of rotatable bonds: 4 ; number of H-bond acceptors and donors: 3 and 2 , respectively. The value of the polar surface area (PSA)

calculated using the topological polar surface area (TPSA), considering sulfur and phosphorus as polar atoms, is $58.04 \AA$
$3 h$

The compound has a molecular weight of $271.36 \mathrm{~g} / \mathrm{mol}$; number of heavy atoms and number of aromatic heavy atoms: 20 and

12 , respectively; number of rotatable bonds: 4 ; number of H-bond acceptors and donors: 3 and 2 , respectively. The value of the polar surface area (PSA) calculated using the topological polar surface area (TPSA), considering sulfur and phosphorus as polar atoms, is $58.04 \AA$ 
Table 4. Cont.

\begin{tabular}{|c|c|c|c|}
\hline & $3 a$ & $3 g$ & $3 h$ \\
\hline Lipophilicity & $\begin{array}{l}\text { The value partition coefficient } \\
\text { between n-octanol and water } \\
(\log \mathrm{Po} / \mathrm{w}) \text { is } 3.72 \text { [32]. It is an } \\
\text { average value of five freely } \\
\text { available predictive models (i.e., } \\
\text { XLOGP3 [33], WLOGP [34], } \\
\text { MLOGP [35,36], SILICOS-IT } \\
\text { [25], and iLOGP) [37]. }\end{array}$ & $\begin{array}{l}\text { The consensus value partition } \\
\text { coefficient between n-octanol } \\
\text { and water }(\log \mathrm{Po} / \mathrm{w}) \text { is } 2.68 \text {. }\end{array}$ & $\begin{array}{l}\text { The consensus value partition } \\
\text { coefficient between n-octanol } \\
\text { and water }(\log \mathrm{Po} / \mathrm{w}) \text { is } 2.92 \text {. }\end{array}$ \\
\hline Water solubility & $\begin{array}{l}\text { Estimated by three predictors. } \\
\text { The value of Log S (ESOL) [38] } \\
\text { is }-4.47 \text {, which makes a } \\
\text { compound moderately soluble. } \\
\text { The predicted value of solubility } \\
\text { is } 1.03 \cdot 10^{-2} \mathrm{mg} / \mathrm{mL} \text {. The value } \\
\text { of log } S \text { (Ali) [39] is }-4.97, \\
\text { which also classifies the } \\
\text { compound as moderately } \\
\text { soluble. The value of solubility } \\
\text { is } 3.30 \times 10^{-3} \text { mg/mL. The } \\
\text { value of log } S \text { (SILICOS-IT) [25] } \\
\text { is }-7.00, \text { which classifies the } \\
\text { compound as poorly soluble. } \\
\text { The predicted value of solubility } \\
\text { is } 3.09 \times 10^{-5} \text { mg/mL. }\end{array}$ & $\begin{array}{l}\text { The value of Log } S \text { (ESOL) is } \\
-3.56 \text {, which classifies a } \\
\text { compound as soluble. The } \\
\text { predicted value of solubility is } \\
7.08 \times 10^{-2} \mathrm{mg} / \mathrm{mL} \text {. The value } \\
\text { of log } \mathrm{S} \text { (Ali) is }-3.94 \text {, which } \\
\text { also classifies the compound as } \\
\text { soluble. The value of solubility } \\
\text { is } 2.99 \times 10^{-2} \mathrm{mg} / \mathrm{mL} \text {. The } \\
\text { value of } \log S \text { (SILICOS-IT) is } \\
-5.26, \text { which classifies the } \\
\text { compound as moderately } \\
\text { soluble. The predicted value of } \\
\text { solubility is } 1.40 \times 10^{-3} \\
\text { mg } / \mathrm{mL} \text {. }\end{array}$ & $\begin{array}{l}\text { The value of Log } S \text { (ESOL) is } \\
-3.74 \text {, which classifies a } \\
\text { compound as soluble. The } \\
\text { predicted value of solubility is } \\
4.97 \times 10^{-2} \mathrm{mg} / \mathrm{mL} \text {. The value } \\
\text { of log } S \text { (Ali) is }-4.12 \text {, which } \\
\text { classifies the compound as } \\
\text { moderately soluble. The } \\
\text { predicted value of solubility is } \\
2.05 \times 10^{-2} \text { mg } / \mathrm{mL} \text {. The value } \\
\text { of log } S \text { (SILICOS-IT) is }-5.65 \text {, } \\
\text { which also classifies the } \\
\text { compound as moderately } \\
\text { soluble. The predicted value of } \\
\text { solubility is } 6.09 \times 10^{-4} \text { mg } / \mathrm{mL} \text {. }\end{array}$ \\
\hline
\end{tabular}

One of the estimated predictors relates to skin permeability coefficient (Kp) [40]. The more negative $\mathrm{Kp}$ is, the less permeant a molecule is. The predicted $\mathrm{Kp}$ value of compound $3 \mathbf{a}$ is $-5.50 \mathrm{~cm} / \mathrm{s}$, the predicted interaction of a molecule with cytochromes

Pharmacokinetics P450 [41,42]. The inhibition of five isoforms, CYP1A2,

CYP2C19, CYP2C9, CYP2D6, and CYP3A4, may cause pharmacokinetics-related drug-drug interactions.

Compound $\mathbf{3 a}$ is predicted to be an inhibitor of all of the five enzyme isoforms.

The predicted $\mathrm{Kp}$ value of compound $3 \mathrm{~g}$ is $-5.70 \mathrm{~cm} / \mathrm{s}$. Compound $3 \mathrm{~g}$ is predicted to be an inhibitor of CYP1A2 and CYP2D6.
The predicted $\mathrm{Kp}$ value of compound $3 \mathrm{~h}$ is $-5.66 \mathrm{~cm} / \mathrm{s}$. Compound $\mathbf{3 g}$ is predicted to be an inhibitor of CYP1A2 and CYP2D6 and CYP3A4.
Estimation of the chance to be an oral drug. The Swiss ADME software bases on five different predictors. Originally used by major pharmaceutical companies aiming to improve the quality of their chemical

Druglikeness substances. The Lipinski (Pfizer) rule of five [43], Ghose (Amgen) [44], Veber (GSK) [45], Egan (Pharmacia) [46], and Muegge (Bayer) [47]. According to all of the predictors, compound $\mathbf{3 a}$ is predicted to have a chance to be an oral drug.
According to all of the five predictors, compound $\mathbf{3 g}$ is predicted to have a chance to be an oral drug.
According to all of the five predictors, compound $3 \mathrm{~h}$ is predicted to have a chance to be an oral drug. 
Table 4. Cont

\begin{tabular}{|c|c|c|c|}
\hline & $3 a$ & $3 g$ & $3 h$ \\
\hline Medicinal chemistry & $\begin{array}{l}\text { Two complementary pattern } \\
\text { recognition methods allow for } \\
\text { the identification of potentially } \\
\text { problematic fragments-assay } \\
\text { interference compounds } \\
\text { (PAINS) [48] and Brenk } \\
\text { Structural alert [49]. Zero } \\
\text { predicted alerts assist in } \\
\text { creating a good druglike } \\
\text { molecule. }\end{array}$ & $\begin{array}{l}\text { Compound } \mathbf{3 g} \text { has zero } \\
\text { predicted structural problematic } \\
\text { fragments. }\end{array}$ & $\begin{array}{l}\text { Compound } 3 \mathrm{~h} \text { has zero } \\
\text { predicted structural problematic } \\
\text { fragments. }\end{array}$ \\
\hline
\end{tabular}

\subsubsection{Molecular Docking Analysis}

The binding pose and affinity between a ligand and an enzyme are very important pieces of information for computer-aided drug design. In the initial stage of a drug discovery project, this information is often obtained by using molecular docking methods. To conduct an effective docking procedure, some conditions have to be fulfilled. The structure of a target protein extracted from X-ray crystallography gives the possibility to omit protein structural changes during the process of binding the same ligand. According to Jones et al. [50], the resolution of the protein-ligand complex should be below $2.5 \AA$. Poor resolution structures result in more incorrect conformations of the ligand generated. Moreover, the complex should have only one ligand in the active site. The results of the target prediction are shown in Table 5. The docking was performed for each target from Table 5. The results are presented for one target-the one for which the docking results were better.

Table 5. List of predicted targets.

\begin{tabular}{cccc}
\hline \multirow{2}{*}{ Compound } & Target Class & Target Name & \multicolumn{2}{c}{ Protein Data Bank (PDB) } \\
Accession Code
\end{tabular}

The results of docking present a prediction of the ligand binding modes, classified by the scoring function as the best. The proteins are presented as "surface", and each ligand is presented as lines (Figures 9-11). 


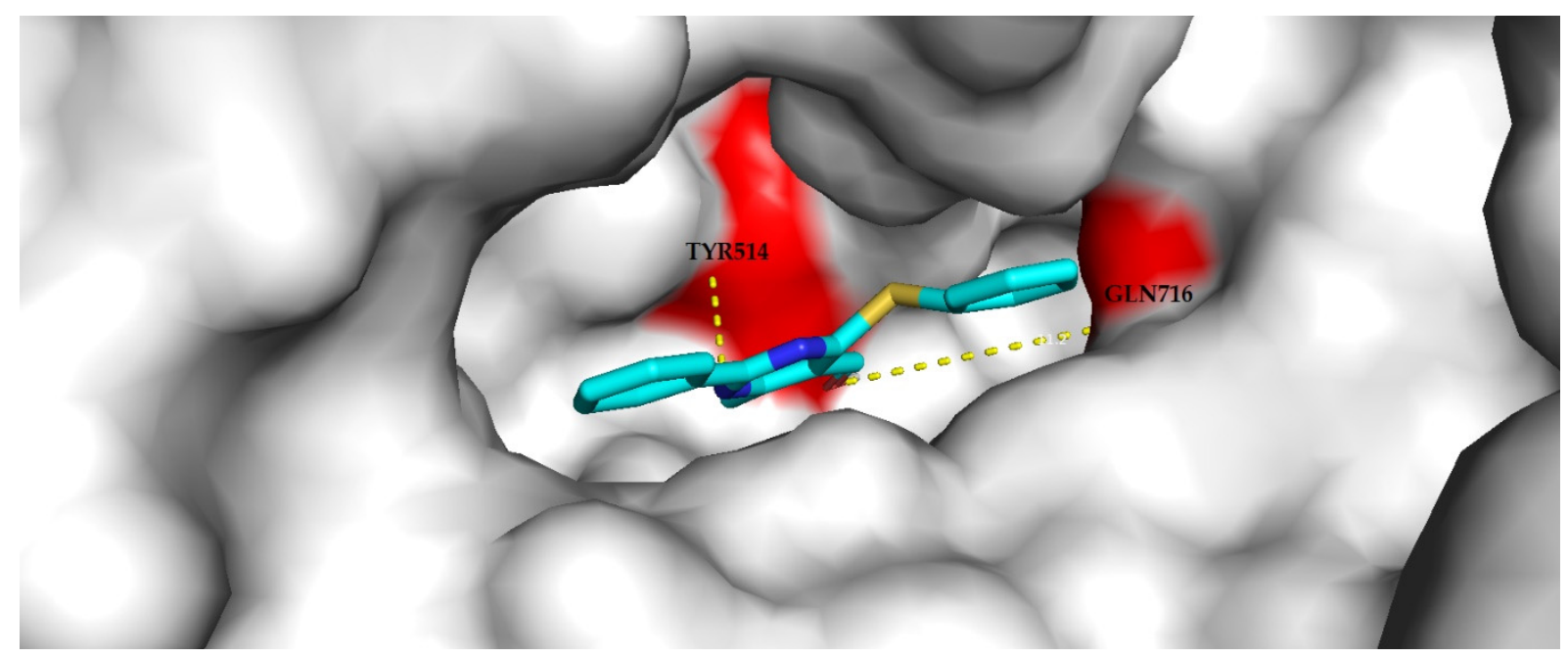

Figure 9. Compound 3a in a phosphodiesterase 10A binding site. Yellow dashes indicate the hydrogen bonding with amino acids in the binding site (colored as red). The presented ligand was top-scored by the scoring function and obtained the lowest RMSD value (1.453 $\AA$ ) after docking in AutoDock Vina.

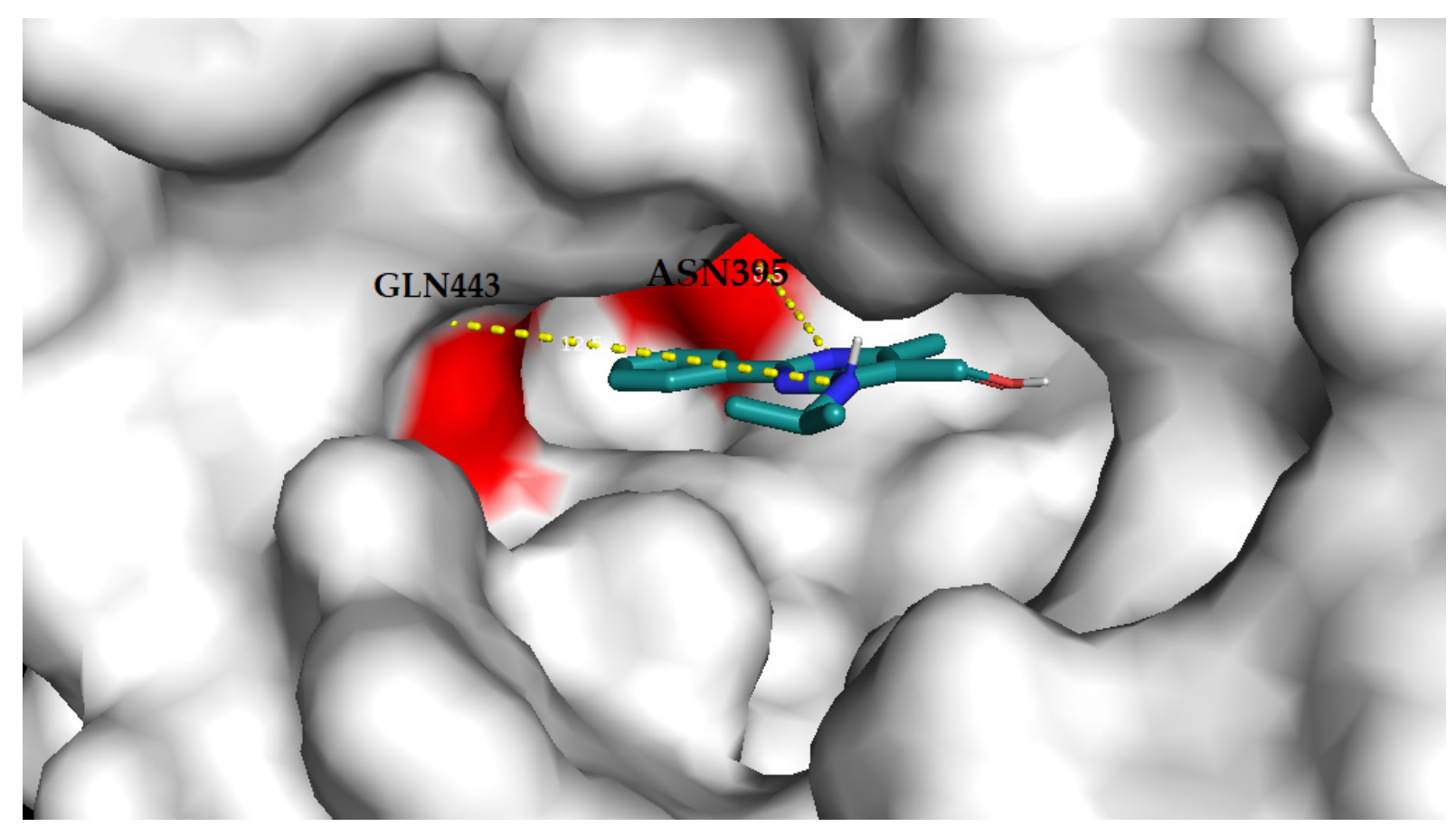

Figure 10. Compound $3 \mathrm{~g}$ in a phosphodiesterase $4 \mathrm{~B}$ binding site. Yellow dashes indicate the hydrogen bonding with amino acids in the binding site (colored as red). The presented ligand was top-scored by the scoring function and obtained the lowest RMSD value (1.015 $\AA$ ) after docking in AutoDock Vina. 


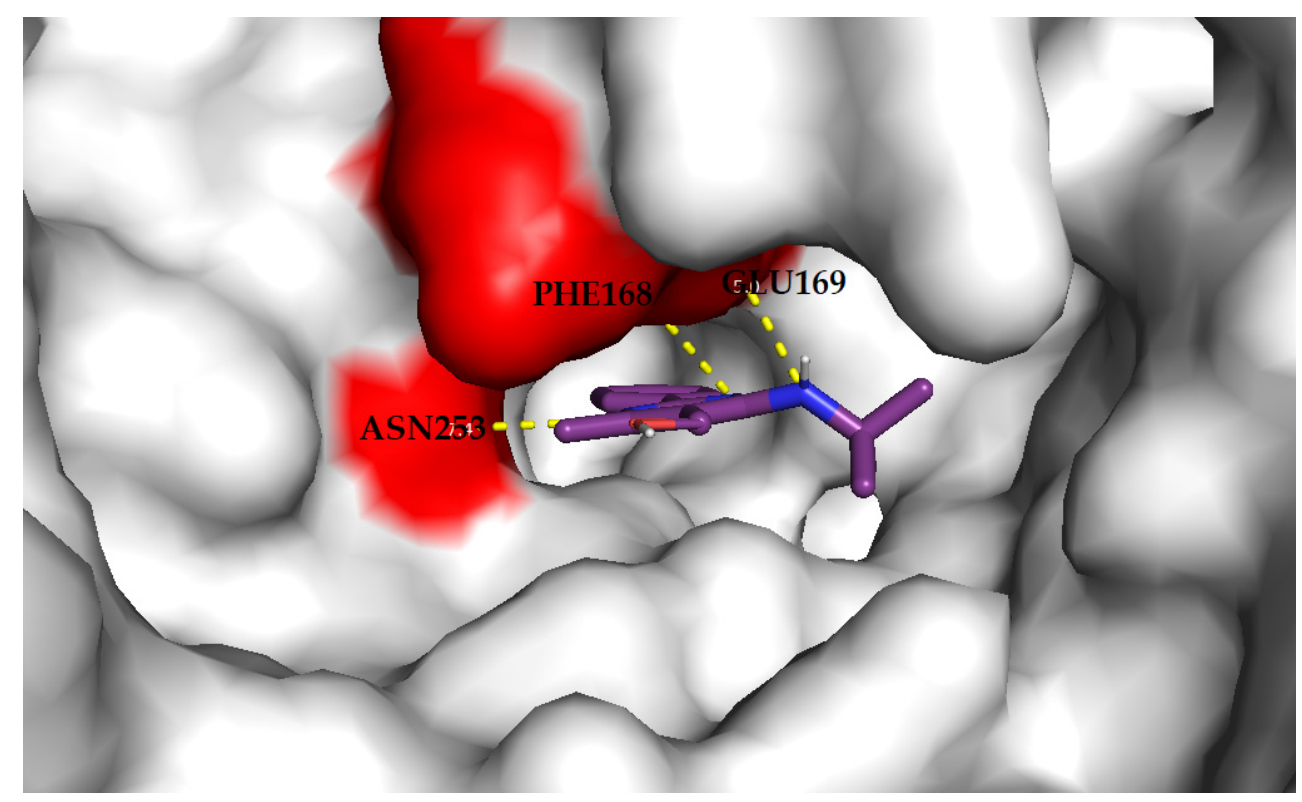

Figure 11. Compound $3 \mathrm{~h}$ in an adenosine A1 binding site. Yellow dashes indicate the hydrogen bonding with amino acids in the binding site (colored as red). The presented ligand was top-scored by the scoring function and obtained the lowest RMSD value (1.417 $\AA$ ) after docking in AutoDock Vina.

\section{Discussion}

The starting esters were obtained by the reaction of 4-sulfanylpyrimidine (1a) with proper benzyl chloride in a methanolic solution of $\mathrm{NaOH}(\mathbf{2} \mathbf{a}$ and $\mathbf{2 b})$ or by coupling the product of chlorination of $1 \mathbf{b}$ with gaseous ammonia (2c) or aliphatic amines $(\mathbf{2} \mathbf{d}-\mathbf{2} \mathbf{j})$. Their reduction yielded a series of 10 new 5-hydroxymethylpyrimidines (3a-3j), which were the subject of further research. The structures of the obtained compounds were established by spectroscopy techniques, and several of them were identical with solid-state structures obtained during $X$-ray measurements.

The molecular structures of $\mathbf{3 c}$ and $\mathbf{3 e}-\mathbf{3 h}$ were studied by single-crystal X-ray diffraction. Compounds $3 \mathbf{c}$ and $\mathbf{3 e}-\mathbf{3 g}$ crystallize in the space group $P 2_{1} / c$ with one molecule in the asymmetric unit, whereas compound $3 \mathrm{~h}$ crystallizes in the space group $P c a 2_{1}$ with two molecules in their asymmetric units. The preferred gauche orientation of the hydroxyl O1 and the pyrimidine $\mathrm{C} 4$ atoms was confirmed by the values of the O1-C51-C5-C4 torsion angle of $49.0-64.5(2)^{\circ}$. Such conformation is stabilized by an intramolecular $\mathrm{N}-\mathrm{H} \cdots \mathrm{O}$ interaction, which closes a six-membered ring with $S(6)$ motif with the exception of $3 f$. It seems that the smaller the absolute value of the O1-C51-C5-C4 torsion angle is, the stronger the intramolecular $\mathrm{N}-\mathrm{H} \cdots \mathrm{O}$ bond becomes. A similar synthon $(\mathrm{S}(6))$, which is formed by an intramolecular interaction of another type $(\mathrm{N}-\mathrm{H} \cdots \mathrm{N})$, can be found in previously studied crystal structures of 2-phenylpyrimidine-4-amine derivatives [13,51]. Generally, in all structures, a similar hydrogen-bonded network can be observed, which involves mainly $-\mathrm{OH}$ moieties as donors (in intermolecular interactions) and acceptors (in intramolecular interactions, except for 3f). Despite the similarity, it should also be mentioned that the structure of $3 \mathrm{~g}$ is subtly different. In the cases of $\mathbf{3 g}$, the amino group is nearly coplanar to the pyrimidine ring, as shown by the N3-C4-N4-C41 torsion angle $0.4(2)^{\circ}$, and additional stabilization of the crystal packing is also provided by weak $\mathrm{C}-\mathrm{H} \cdots \mathrm{O}$ hydrogen bonding interactions, involving the isopropyl and hydroxyl groups.

All the obtained 5-hydroxymethylpyrimidines were tested for their cytotoxicity against normal cells on the RPTEC cell line with a neutral red uptake assay. Generally, pyrimidines possessing a 4-benzylsulfanyl group ( $3 \mathbf{a}$ and $\mathbf{3 b}$ ) exhibit stronger toxicity than their amino analogues $(\mathbf{3} \mathbf{c}-\mathbf{3} \mathbf{j})$. Considering our previous observation [14], it appears that the substitution in the phenyl ring of the benzyl group, with both electron-withdrawing (4- $\mathrm{Cl})$ 
and electron-donating groups $\left(2-\mathrm{CH}_{3}, \mathbf{3} \mathbf{b}\right)$, enhances their toxic properties. Compound $\mathbf{3 b}$ decreased the cell viability in low concentration and, for this reason, was excluded from further biological investigations.

Pyrimidines with primary or secondary amino groups at the 4-position $(\mathbf{3} \mathbf{c}-3 \mathbf{j})$ show relatively low toxicity in a wide range of concentrations with the exception of compound $3 \mathbf{j}$. It seems that the substitution of the primary amino group of compound $3 \mathbf{c}$ with n-alkyls (ethyl-3d, n-propyl-3e), unsaturated alkyl (allyl-3f), branched alkyls (isopropyl-3g, $t$-butyl3 h), or hydroxyalkyl groups (2-hydroxyethyl-3i) exerts an insignificant impact on their cytotoxicity. The substantial growth of toxicity can be seen in the case of compound $\mathbf{3} \mathbf{j}$, which possesses a sizable cyclohexyl substituent at the amino group and, because of that, was excepted from further tests.

The anticancer investigation showed that only three out of eight tested compounds demonstrated antineoplastic properties. Derivative 3a with a 4-benzylsulfanyl group exhibited low toxicity to HepaRG and AGS cell lines. Among derivatives with 4-amino groups, only two exhibited moderate toxicity, namely, those with bulky substituents as isopropyl (3g) and t-butyl (3h) groups. At the same time, $3 \mathbf{h}$ was found to reach the lowest IC50 among tested compounds $(132.2 \mu \mathrm{M})$. On the other hand, $\mathbf{3 g}$ demonstrated the broadest range of toxicity against cancer cell lines (HeLa, HepaRG, A172). As mentioned above, HepaRG was the most susceptible line to tested compounds. It is also noteworthy that the substitution of the primary amino group of $3 \mathrm{c}$ with various alkyl groups does not affect their anticancer properties, and the enhancement is evident only in the case of branched substituents.

Selected compounds for ADME analysis predict similar physiochemical properties and have comparable molecular weights, rotatable bonds, number of hydrogen bond donors/acceptors and water solubility, druglikeness, and medicinal chemistry properties. Due to the lipophilicity of all the investigated compounds, a partition coefficient was less than 5 , and $3 \mathrm{~g}$ has the lowest partition coefficient between $\mathrm{n}$-octanol and water. Moreover 3a has the best predicted pharmacokinetic properties.

The docking of compound 3a to the phosphodiesterase 10A binding site (Figure 9) resulted in nine generated poses of the ligand with the top-scored generated pose no. 4 with an affinity of $-8.9 \mathrm{kcal} / \mathrm{mol}$ and an RMSD of $1.453 \AA$. The compound forms hydrogen bonding with Tyr514 and Gln716 in the binding site of the enzyme. The docking of compound $3 \mathrm{~g}$ to the phosphodiesterase $4 \mathrm{~B}$ binding site (Figure 10) resulted in nine generated poses of the ligand with the top-scored generated pose no. 2 with an affinity of $-8.9 \mathrm{kcal} / \mathrm{mol}$ and an RMSD of $1.015 \AA$. The compound forms hydrogen bonding with Gln443 and Asn395 in the binding site of the enzyme. The docking of compound $3 \mathrm{~h}$ to the adenosine A1 receptor binding site (Figure 11) resulted in nine generated poses of the ligand with the top-scored generated pose no. 6 with an affinity of $-8.4 \mathrm{kcal} / \mathrm{mol}$ and an RMSD of $1.417 \AA$. The compound forms hydrogen bonding with Glu169 and Asn253, Phe168 in the binding site of the enzyme.

The tested compounds exhibited weak antimicrobial properties. Only 3a with a 4benzylsulfanyl group demonstrated any antifungal activity (MIC against $C$. albicans $=$ $256 \mu \mathrm{g} / \mathrm{mL}$ ), but it had no antibacterial features. Among the derivatives with a 4-amino group, compounds with smaller than three carbon chains exhibited no antimicrobial properties (3c with a primary amino group, $\mathbf{3} \mathbf{d}$ with ethyl, and $3 \mathbf{i}$ with 2-hydroxyethyl groups). The extension of the carbon chain slightly enhances the antibacterial potency of the reminder. The lowest MIC was observed in the case of $\mathbf{3 g}$ with an isopropyl substituent against $E$. coli $(\mathrm{MIC}=128 \mu \mathrm{g} / \mathrm{mL}$ ). A. baumannii was the most sensitive bacterium to the tested compounds.

\section{Conclusions}

Based on our previous research, we obtained a series of novel 5-hydroxymethylpyrimidines, $\mathbf{3 a}-\mathbf{3} \mathbf{j}$, which vary in the 4 -position by the reduction of proper esters, $\mathbf{2} \mathbf{a}-\mathbf{2} \mathbf{j}$, with $\mathrm{LiAlH}_{4}$. 
The compounds were characterized using spectroscopic and some of them (3c and $3 \mathbf{e}-3 \mathbf{h})$ also X-ray crystallography methods.

Except for $3 \mathbf{h}$, which crystallized in the $P c a 2_{1}$ space group, the other studied compounds crystallized in the $P 2_{1} / c$ space group. The preferred gauche orientation of the $-\mathrm{OH}$ group with respect to the pyrimidine $\mathrm{C} 4$ atom is stabilized by an intramolecular $\mathrm{N}-\mathrm{H} \cdots \mathrm{O}$ hydrogen bond, with the exception of $\mathbf{3 f}$. On the whole, a hydrogen-bonded network structure involves primarily - $\mathrm{OH}$ moieties as donors (in intermolecular interactions) and acceptors (in intramolecular interactions, except for 3f). Furthermore, in the case of the crystal packing of $3 \mathrm{~g}$, weak $\mathrm{C}-\mathrm{H} \cdots \mathrm{O}$ hydrogen bonding interactions involving the isopropyl and hydroxyl groups are also observed.

The cytotoxic test against normal cells on the RPTEC cell line showed that compounds with benzyl sulfanyl groups at the 4-position are generally more toxic than those with amino groups at the 4-position, except for $3 \mathbf{j}$, which possesses a sizable cyclohexyl group. Thus, 2 out of 10 compounds were excluded from further investigation, $3 \mathbf{b}$ with a 2-methylbenzyl sulfanyl group at the 4-position and $\mathbf{3} \mathbf{j}$, mentioned above.

We examined the anticancer activity of the compounds on various cancer cell lines, including HeLa, HepaRG, Caco-2, AGS, and A172, and their antimicrobial properties on six bacterial strains and one strain of fungi. On the whole, the compounds showed weak biological activity. Compound $3 g$ exhibited the broadest range of toxicity against cancer cell lines (HeLa, HepaRG, A172), while $3 \mathrm{~h}$ reached the lowest IC50 among tested compounds (132.2 $\mu \mathrm{M}$ against HepaRG).

Furthermore, in silico analysis reported that ligands that interact with selected enzymes that have been used as docking targets might have moderate therapeutic activity. For instance, the tested compounds have similar values of binding affinities. Nevertheless, the docking of $\mathbf{3 g}$ in the enzyme binding site showed the least value of RMSD.

Regarding microbial activity, only compound 3a with a benzyl sulfanyl group at the 4-position showed any antifungal properties $\left(\mathrm{MIC}=256 \mu \mathrm{g} \mathrm{mL}^{-1}\right.$ ). Compound $\mathbf{3 g}$ demonstrated the lowest MIC among the tested compounds (MIC $=128 \mu \mathrm{g} \mathrm{mL}^{-1}$ against E. coli).

It is worth mentioning that 5-hydroxymethylpyrimidines that possess bulky amino constituents at the 4-position (3g-isopropyl and 3h-t-butyl) showed the best anticancer and antibacterial properties among tested derivatives, which can be a valuable foothold for further research.

Supplementary Materials: The following are available online at https:/ /www.mdpi.com/article/ 10.3390/ma14226916/s1: Figures S1-S10. ${ }^{1}$ HNMR spectra of compounds 2a-2j; Figures S11-S20. ${ }^{1}$ HNMR spectra of compounds $3 \mathbf{a}-\mathbf{3} \mathbf{j}$; Figures S21-S30. MS spectra of compounds $\mathbf{2} \mathbf{a}-\mathbf{2} \mathbf{j}$; Figures S31-S40. MS spectra of compounds 3a-3j; Figures S41-S50. IR spectra of compounds 2a-2j; Figures S51-S60. IR spectra of compounds 3a-3j; Figure S61. A packing diagram of $\mathbf{3 c}$ viewed along the a-axis, showing the formation of a $2 \mathrm{D}$ hydrogen-bonded network through intermolecular interactions, with $\mathrm{O}-\mathrm{H} \cdots \mathrm{N}$ in red and $\mathrm{N}-\mathrm{H} \cdots \mathrm{N}$ in cyan. Dashed lines in black indicate intramolecular $\mathrm{N}-\mathrm{H} \cdots \mathrm{O}$ hydrogen bonds. Symmetry codes: (i) $\mathrm{x},-\mathrm{y}+3 / 2, \mathrm{z}-1 / 2$, and (ii) $-\mathrm{x}+1,-\mathrm{y}+1,-\mathrm{z}$; Table S1. Selected crystallographic data and structure refinements for $\mathbf{3 a}$ and $\mathbf{3 e}-\mathbf{3 h}$; Table S2. Comparison of selected geometrical parameters of compounds $3 \mathrm{c}$ and $3 \mathbf{e}-3 \mathbf{h}$.

Author Contributions: Conceptualization, M.S., A.M.-W., and I.B.; methodology, M.S., A.M.-W., and I.B.; software, M.S., A.M.-W., I.B., A.M., M.K., and A.W.; validation, M.S., A.M.-W., and I.B.; formal analysis, M.S., A.M.-W., I.B., A.M., A.W., M.K., and A.P.; investigation, M.S., A.M.-W., I.B., A.M., and A.W.; resources, M.S., A.M.-W., I.B., and A.P.; data curation, M.S., A.M.-W., I.B., A.M., and A.W.; writing-original draft preparation, M.S., A.M.-W., I.B., A.M., M.K., and A.W.; writing-review and editing, M.S., A.M.-W., and I.B.; visualization, M.S., A.M.-W., I.B., A.M., M.K., and A.W.; supervision, M.S., A.M.-W., and I.B.; project administration, M.S., and A.M.-W.; funding acquisition, A.M.-W., and I.B. All authors have read and agreed to the published version of the manuscript.

Funding: This research was supported financially by Wroclaw Medical University (grant numbers: SUB.D250.21.087 and SUB.D140.21.113). 
Institutional Review Board Statement: Not applicable.

Informed Consent Statement: Not applicable.

Data Availability Statement: Data can be found in the article or Supplementary Materials.

Conflicts of Interest: The authors declare no conflict of interest. The funders had no role in the study design, collection, analyses, or interpretation of data; the writing of the manuscript; or the decision to publish the results.

\section{References}

1. Lagoja, I.M. Pyrimidine as constituent of natural biologically active compounds. Chem. Biodivers. 2005, 2, 1-50. [CrossRef]

2. Rashid, H.; Martines, M.A.U.; Duarte, A.P.; Jorge, J.; Rasool, S.; Muhammad, R.; Ahmad, N.; Umar, M.N. Research developments in the syntheses, anti-inflammatory activities and structure-activity relationships of pyrimidines. RSC Adv. 2021, 11, 6060-6098. [CrossRef]

3. Eicher, T.; Hauptmann, S.; Speicher, A. The Chemistry of Heterocycles; Wiley-VCH Verlag GmbH \& Co. KGaA: Weinheim, Germany, 2003; ISBN 978-3-527-30720-3.

4. Ito, S.; Shen, L.; Dai, Q.; Wu, S.C.; Collins, L.B.; Swenberg, J.A.; He, C.; Zhang, Y. Tet proteins can convert 5-methylcytosine to 5-formylcytosine and 5-carboxylcytosine. Science 2011, 333, 1300-1303. [CrossRef]

5. Branco, M.R.; Ficz, G.; Reik, W. Uncovering the role of 5-hydroxymethylcytosine in the epigenome. Nat. Rev. Genet. 2011, 13, 7-13. [CrossRef] [PubMed]

6. Bjelland, S.; Eide, L.; Time, R.W.; Stote, R.; Eftedal, I.; Volden, G.; Seeberg, E. Oxidation of thymine to 5-formyluracil in DNA: Mechanisms of formation, structural implications, and base excision by human cell free extracts. Biochemistry 1995, 34, 14758-14764. [CrossRef]

7. Franchini, D.-M.; Schmitz, K.-M.; Petersen-Mahrt, S.K. 5-methylcytosine DNA demethylation: More than losing a methyl group. Annu. Rev. Genet. 2012, 46, 419-441. [CrossRef]

8. Yang, H.; Liu, Y.; Bai, F.; Zhang, J.-Y.; Ma, S.-H.; Liu, J.; Xu, Z.-D.; Zhu, H.-G.; Ling, Z.-Q.; Ye, D.; et al. Tumor development is associated with decrease of TET gene expression and 5-methylcytosine hydroxylation. Oncogene 2013, 32, 663-669. [CrossRef]

9. Huang, H.; Jiang, X.; Li, Z.; Li, Y.; Song, C.-X.; He, C.; Sun, M.; Chen, P.; Gurbuxani, S.; Wang, J.; et al. TET1 plays an essential oncogenic role in MLL-rearranged leukemia. Proc. Natl. Acad. Sci. USA 2013, 110, 11994-11999. [CrossRef] [PubMed]

10. Tanaka, F.; Takeuchi, S.; Tanaka, N.; Yonehara, H.; Umezawa, H.; Sumiki, Y. Bacimethrin, a new antibiotic produced by B. megatherium. J. Antibiot. 1961, 14, 161-162. [CrossRef]

11. Reddick, J.J.; Saha, S.; Melnick, J.S.; Perkins, J.; Begley, T.P. The mechanism of action of bacimethrin, a naturally occurring thiamin antimetabolite. Bioorg. Med. Chem. Lett. 2001, 11, 2245-2248. [CrossRef]

12. Ulbricht, T.L.V.; Price, C.C. The synthesis of some pyrimidine metabolite analogs1. J. Org. Chem. 1956, 21, 567-571. [CrossRef]

13. Cieplik, J.; Stolarczyk, M.; Pluta, J.; Gubrynowicz, O.; Bryndal, I.; Lis, T.; Mikulewicz, M. Synthesis and antibacterial properties of pyrimidine derivatives. Acta Pol. Pharm 2015, 72, 53-64.

14. Stolarczyk, M.; Bryndal, I.; Matera-Witkiewicz, A.; Lis, T.; Królewska-Golińska, K.; Cieślak, M.; Kaźmierczak-Barańska, J.; Cieplik, J. Synthesis, crystal structure and cytotoxic activity of novel 5-methyl-4-thio pyrimidine derivatives. Acta Crystallogr. C 2018, 74, 1138-1145. [CrossRef] [PubMed]

15. Goerdeler, J.; Pohland, H.W. Darstellung und cyclisierung von $\alpha$-acyl- $\beta$-amino-thiocrotonamiden. Chem. Ber. 1963, 96, 526-533. [CrossRef]

16. Moustafa, A.H.; Assy, M.G.; Amr, E.A.; Saber, R.M. Studies on the chemical reactivity of ethyl 4-sulfanyl-6-methyl-2phenylpyrimidine-5-carboxylate. Curr. Org. Chem. 2011, 15, 1661-1668. [CrossRef]

17. Dorokhov, V.A.; Gordeev, M.F.; Komkov, A.V.; Bogdanov, V.S. Synthesis of 4-amino-5-alkoxycarbonyl(acyl)pyrimidines from $\beta$-dicarbonyl compounds and n-cyanoamidines. Russ. Chem. Bull. 1990, 39, 130-134. [CrossRef]

18. CrysAlis PRO; Agilent Technologies Ltd.: Yarnton, Oxfordshire, UK, 2014; Available online: https://www.rigaku.com/products/ crystallography/crysalis (accessed on 15 June 2021).

19. Sheldrick, G.M. A short history of SHELX. Acta Crystallogr. A 2008, 64, 112-122. [CrossRef]

20. Sheldrick, G.M. Crystal structure refinement with SHELXL. Acta Crystallogr. C 2015, 71, 3-8. [CrossRef]

21. Brandenburg, K. DIAMOND; Crystal Impact GbR: Bonn, Germany, 1999.

22. Spek, A.L. Structure validation in chemical crystallography. Acta Crystallogr. D 2009, 65, 148-155. [CrossRef]

23. Repetto, G.; del Peso, A.; Zurita, J.L. Neutral red uptake assay for the estimation of cell viability/cytotoxicity. Nat. Protoc. 2008, 3, 1125-1131. [CrossRef] [PubMed]

24. Daina, A.; Michielin, O.; Zoete, V. SwissADME: A free web tool to evaluate pharmacokinetics, drug-likeness and medicinal chemistry friendliness of small molecules. Sci. Rep. 2017, 7, 1-13. [CrossRef]

25. Silicos-It | Filter-It ${ }^{\mathrm{TM}}$. Available online: http:/ / silicos-it.be.s3-website-eu-west-1.amazonaws.com/software/filter-it/1.0.2/filterit.html (accessed on 11 October 2021).

26. Daina, A.; Michielin, O.; Zoete, V. SwissTargetPrediction: Updated data and new features for efficient prediction of protein targets of small molecules. Nucleic Acids Res. 2019, 47, W357-W364. [CrossRef] 
27. Dolinsky, T.J.; Nielsen, J.E.; McCammon, J.A.; Baker, N.A. PDB2PQR: An automated pipeline for the setup of poisson-boltzmann electrostatics calculations. Nucleic Acids Res. 2004, 32, W665-W667. [CrossRef] [PubMed]

28. Morris, G.M.; Huey, R.; Lindstrom, W.; Sanner, M.F.; Belew, R.K.; Goodsell, D.S.; Olson, A.J. AutoDock4 and AutoDockTools4: Automated docking with selective receptor flexibility. J. Comput. Chem. 2009, 30, 2785-2791. [CrossRef]

29. Trott, O.; Olson, A.J. AutoDock vina: Improving the speed and accuracy of docking with a new scoring function, efficient optimization and multithreading. J. Comput. Chem. 2010, 31, 455. [CrossRef]

30. Bernstein, J.; Davis, R.E.; Shimoni, L.; Chang, N.-L. Patterns in hydrogen bonding: Functionality and graph set analysis in crystals. Angew. Chem. Int. Ed. 1995, 34, 1555-1573. [CrossRef]

31. Ertl, P.; Rohde, B.; Selzer, P. Fast calculation of molecular polar surface area as a sum of fragment-based contributions and its application to the prediction of drug transport properties. J. Med. Chem. 2000, 20, 3714-3717. [CrossRef] [PubMed]

32. Mannhold, R.; Poda, G.I.; Ostermann, C.; Tetko, I.V. Calculation of molecular lipophilicity: State-of-the-art and comparison of log P methods on more than 96,000 compounds. J. Pharm. Sci. 2009, 98, 861-893. [CrossRef] [PubMed]

33. Cheng, T.; Zhao, Y.; Li, X.; Lin, F.; Xu, Y.; Zhang, X.; Li, Y.; Wang, R.; Lai, L. Computation of octanol-water partition coefficients by guiding an additive model with knowledge. J. Chem. Inf. Model. 2007, 47, 2140-2148. [CrossRef]

34. Wildman, S.; Crippen, G. Prediction of physicochemical parameters by atomic contributions. J. Chem. Inform. Comput. Sci. 1999, 5, 868-873. [CrossRef]

35. Moriguchi, I.; Hirono, S.; Liu, Q.; Nakagome, I.; Matsushita, Y. Simple Method of calculating octanol/water partition coefficient. Chem. Pharm. Bull. 1992, 40,127-130. [CrossRef]

36. Moriguchi, I.; Hirono, S.; Nakagome, I.; Hirano, H. Comparison of reliability of log p values for drugs calculated by several methods. Chem. Pharm. Bull. 1994, 42, 976-978. [CrossRef]

37. Daina, A.; Michielin, O.; Zoete, V. iLOGP: A simple, robust, and efficient description of n-octanol/water partition coefficient for drug design using the GB/SA approach. J. Chem. Inf. Model. 2014, 54, 3284-3301. [CrossRef]

38. Delaney, J.S. ESOL: Estimating aqueous solubility directly from molecular structure. J. Chem. Inf. Comput. Sci. 2004, 44, 1000-1005. [CrossRef] [PubMed]

39. Ali, J.; Camilleri, P.; Brown, M.; Hutt, A.J.; Kirton, S.B. Revisiting the general solubility equation: In silico prediction of aqueous solubility incorporating the effect of topographical polar surface area. J. Chem. Inf. Model. 2012, 52, 420-428. [CrossRef]

40. Potts, R.O.; Guy, R.H. Predicting skin permeability. Pharm. Res. 1992, 9, 663-669. [CrossRef] [PubMed]

41. Wolf, C.R.; Smith, G.; Smith, R.L. Science, medicine, and the future: Pharmacogenetics. BMJ 2000, 320, 987-990. [CrossRef] [PubMed]

42. Di, L. The role of drug metabolizing enzymes in clearance. Expert Opin. Drug Metab. Toxicol. 2014, 10, 379-393. [CrossRef] [PubMed]

43. Lipinski, C.; Lombardo, F.; Dominy, B.W.; Fenney, P.J. Experimental and computational approaches to estimate solubility and permeability in drug discovery and development settings. Adv. Drug Deliv. Rev. 2001, 46, 3-26. [CrossRef]

44. Arup, G.; Viswanadhan, V.N.; Wendoloski, J.J. A knowledge-based approach in designing combinatorial or medicinal chemistry libraries for drug discovery. 1. A qualitative and quantitative characterization of known drug databases. J. Comb. Chem. 1999, 1, 55-68. [CrossRef]

45. Veber, D.F.; Johnson, S.R.; Cheng, H.-Y.; Smith, B.R.; Ward, K.W.; Kopple, K.D. Molecular properties that influence the oral bioavailability of drug candidates available. J. Med. Chem. 2002, 45, 2615-2623. [CrossRef]

46. Egan, W.J.; Merz, K.M.J.; Baldwin, J.J. Prediction of drug absorption using multivariate statistics. J. Med. Chem. 2000, 43, 3867-3877. [CrossRef] [PubMed]

47. Muegge, I.; Heald, S.L.; Brittelli, D. Simple selection criteria for drug-like chemical matter. J. Med. Chem. 2001, 44, 1841-1846. [CrossRef]

48. Baell, J.B.; Holloway, G.A. New substructure filters for removal of pan assay interference compounds (PAINS) from screening libraries and for their exclusion in bioassays. J. Med. Chem. 2010, 53, 2719-2740. [CrossRef] [PubMed]

49. Brenk, R.; Schipani, A.; James, D.; Krasowski, A.; Gilbert, I.H.; Frearson, J.; Wyatt, P.G.W. Lessons learnt from assembling screening libraries for drug discovery for neglected diseases. ChemMedChem 2008, 3, 435-444. [CrossRef] [PubMed]

50. Jones, G.; Willet, P.; Glen, R.C.; Leach, A.R.; Taylor, R. Development and validation of a genetic algorithm for flexible docking. J. Mol. Biol. 1997, 267, 727-748. [CrossRef]

51. Stolarczyk, M.; Wolska, A.; Mikołajczyk, A.; Bryndal, I.; Cieplik, J.; Lis, T.; Matera-Witkiewicz, A. A new pyrimidine schiff base with selective activities against enterococcus faecalis and gastric adenocarcinoma. Molecules 2021, 26, 2296. [CrossRef] [PubMed] 